\title{
Chapter
}

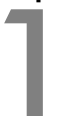

\section{Income and Price Effects in Foreign Trade*}

\author{
Morris Goldstein and Mohsin S. Khan
}

\section{INTRODUCTION}

Few areas in all of economics, and probably none within international economics itself, have been subject to as much empirical investigation over the past thirty five years as the behavior of foreign trade flows. Reasons for this unusual degree of attention are not hard to find. First, the data base is a rich one. ${ }^{1}$ Statistics on the value of imports and exports extend over long time periods and can be disaggregated by commodity and by region

\footnotetext{
*The views expressed are the sole responsibility of the authors and do not necessarily reflect the views of the IMF. We are grateful to Jacques Artus, William Branson, Robert Cumby, Michael Dooley, David Folkerts-Landau, John Helliwell, William Hemphill, Peter Kenen, Malcolm Knight, Anne McGuirk, and Tim Padmore for helpful comments on an earlier draft.

${ }^{1}$ The availability of trade data was surely a contributing factor to the advanced nature of the early empirical work on trade models. It is sufficient to note that by 1957 there already existed, inter alia: (i) at least 42 books and articles containing estimates of income and price elasticities for imports and exports [see Cheng's (1959) survey]; (ii) several superb methodological criticisms [Orcutt (1950), Harberger (1953)] that explained why estimated price elasticities could differ from the true elasticities; and (iii) at least one complete simultaneous model of import demand and supply [Morgan and Corlett (1951)], actually estimated by limited-information maximum likelihood methods, that displays the authors' awareness of many of the methodological issues that still entertain current research.
} 
of origin or destination to a relatively fine level. ${ }^{2}$ Second, the underlying theoretical framework for the determination of trade volumes and prices is a familiar one from consumer demand and production theory, and can make do with relatively few explanatory variables, most of which have accessible empirical counterparts. Third, the estimated income and price elasticities of demand and supply have seemingly wide application to a host of important macro-economic policy issues, including but not limited to: the international transmission of changes in economic activity and prices, the impact of both expenditure-reducing (monetary and fiscal) policies and expenditureswitching (exchange rate, tariff, subsidy) policies on a country's trade balance, the welfare and employment implications of changes in own or partnercountries' trade restrictions, and the severity of external balance constraints on domestic policy choices.

In this chapter the aim is to identify, summarize, and evaluate the main methodological and policy issues that have surrounded the estimation of trade equations. By "trade equations" we mean equations for the time-series behavior of the quantities and prices of merchandise imports and exports, ${ }^{3}$ and as the title of the chapter suggests, we focus explicitly on the role played by income and prices in the determination of these trade variables.

Our task is made easier by the admirable coverage of the early empirical literature and of many specific topics in trade modelling in previous survey papers. Indeed, trade surveys have appeared at least once every five years since 1959. Early (1936-57) estimates of income propensities and price elasticities have been surveyed and evaluated by Cheng (1959) and by Prais (1962). Early world trade models are discussed in Taplin (1973), and more recent multicountry models are compared and analyzed by Deardorff and Stern (1977) and by Fair (1979). Special mention should be made of the comprehensive trade surveys of Leamer and Stern (1970), Magee (1975), and Stern et al. (1976). The Leamer and Stern (1970) book has, among other things, a lucid discussion of the time-series estimation of import and export demand relationships. In this chapter we have tried to update and expand upon their analysis of methodological issues; in particular; we devote more attention to

\footnotetext{
${ }^{2}$ Branson (1980), for example, in his paper on trends in U.S. international trade, present data on U.S. trade balances by end-use commodity that extend back to 1925 .

${ }^{3}$ Empirical work on international trade in services (or "invisibles") is still quite limited; see Bond (1980) and the references cited therein.
} 
supply relationships. ${ }^{4}$ Magee's (1975) trade survey is the broadest one available, encompassing methodological questions, empirical evidence, pure trade and monetary theory, and associated policy issues. We inevitably therefore cover some of the same ground but we have tried to minimize duplication. ${ }^{5}$ Finally, Stern et al. (1976) have provided an exhaustive annotated bibliography of price elasticity studies in international trade spanning the 1960-1975 period, as well as summary tables of "median" price elasticities broken down by commodity group and by country. We offer our own updated "consensus" price and income elasticities which partially reflect Stern et al.'s (1976) findings but which also give higher weights to what we regard as the better quality estimates. ${ }^{6}$

The plan of the chapter is as follows. Section 2 addresses the main methodological issues in the specification of trade models. This is basically a discussion about what variables ought in theory to be included in demand and supply functions for imports and exports, what choices and compromises have to be made in the measurement of these variables, and what light existing evidence throws on the choice among competing specifications. Section 3 is concerned with what we call econometric issues in trade modelling. The subjects covered are the treatment of dynamics and time lags, aggregation, simultaneity, and stability of the relationships concerned. Section 4 turns to the empirical estimates of income and price elasticities themselves and to the policy implications of those estimates. Summary tables are constructed from recent empirical studies to illustrate the revealed "consensus", or lack of it, on (i) long-run price and income elasticities of demand for total merchandise

\footnotetext{
${ }^{4}$ We have placed much less emphasis than Leamer and Stern (1970) on the theory and measurement of the elasticity of substitution in international trade and on index number problems associated with aggregation. Further, we do not deal at all with constant-marketshare analysis of export growth.

${ }^{5}$ Specifically, we have provided only passing reference to Orcutt's (1950) criticisms of estimated price elasticities; to conflicts between Keynesian, absorption, and monetary approaches to the balance of payments; to estimates of the effects of tariff reductions on trade, and to earlier world trade models. Instead, we have substituted discussions of econometric issues involved with modelling of trade relationships, factors responsible for inter-country differences in price elasticities, feedback effects of exchange rate changes on domestic prices, and conflicts between specifications of demand and supply in trade models and those currently in vogue elsewhere in macroeconomics.

${ }^{6}$ Like the other trade surveys, our review of the empirical evidence concentrates on industrialcountry trade. An up-to-date survey of empirical trade models for developing countries still waits to be written.
} 
imports and exports; (ii) the difference between short-run and long-run price elasticities of demand; (iii) price and activity elasticities for broad commodity classes of imports; (iv) supply price elasticities for exports, (v) the so-called "pass-through" of exchange rate changes onto the domestic currency prices of imports and exports; (vi) the elasticity of export price with respect to domestic prices (or labor costs) and competitors' export prices; and (vii) the "feedback" effect of exchange rate changes on domestic prices. Drawing on this evidence, broad conclusions are advanced on the effectiveness of devaluation. Section 5 offers some concluding observations as well as suggestions for further research.

\section{SPECIFICATION ISSUES IN TRADE MODELLING}

How should the time-series behavior of imports and exports be modelled? In our view, the appropriate model depends on, among other things, the type of good being traded (perfectly homogeneous primary commodities versus highly differentiated manufactured goods), on the end-use to which the traded commodity is being put (whether for final consumption or as a factor input), on the institutional framework under which trade takes place (an economy where resources are allocated via relative prices versus one where administrative controls play the predominant role in allocation), on the purpose of the modelling exercise (forecasting versus hypothesis testing), and sometimes even on the availability of data (e.g. if reliable data exist on trade values but not on volumes).

Nevertheless, it still makes sense as a framework for the discussion of particular specification issues to set out the two general models of trade that have dominated the empirical literature, namely, the imperfect substitutes model and the perfect substitutes model. Since most trade studies have dealt with aggregate imports (exports), the two models have often been viewed as competitors. Once disaggregation is admitted, however, there is no reason why the two models should not be seen as complements — one dealing with trade for differentiated goods, and the other with trade for close — if not perfect substitutes. ${ }^{7}$

${ }^{7}$ Clark (1977) is one of the few studies that actually follows this guideline. 


\subsection{The Imperfect Substitutes Model}

The key underlying assumption of the imperfect substitutes model is that neither imports nor exports are perfect substitutes for domestic goods. Support for this assumption comes from two sources. First, there is the (debating) argument that if domestic and foreign goods were perfect substitutes, then one should observe: (i) either the domestic or foreign good swallowing up the whole market when each is produced under constant (or decreasing) costs [Magee (1975)]; and (ii) each country as an exporter or importer of a traded good but not both [Rhomberg (1973)]. Since both of these predictions are counter to fact at both the aggregate and disaggregated level, i.e. one normally observes the coexistence of imports and domestic output and the flourishing of two-way trade, the perfect substitutes hypothesis can be rejected. The second bit of evidence is more direct. A large number of empirical studies [Kreinen and Officer (1978), Isard (1977b), Kravis and Lipsey (1978)] have shown that, even at the most disaggregated level for which comparable data can be gathered, there are significant and nontransitory price differences for the "same" product in different countries (after translation into a common currency), as well as between the domestic and export prices of a given product in the same country. In short, the "law of one price" does not seem to hold either across or within countries, except perhaps for standard commodities such as wheat or copper that are sold on international commodity exchanges. ${ }^{8}$ It would appear therefore that finite price elasticities of demand and supply can in fact be estimated for most traded goods.

In eqs. (1)-(8) below, we present a "bare-bones" imperfect substitutes model of country i's imports from, and exports to, the rest of the world $\left({ }^{*}\right)$ :

$$
\begin{aligned}
I_{i}^{\mathrm{d}} & =f\left(Y_{i}, P I_{i}, P_{i}\right), \quad f_{1}, f_{3}>0, \quad f_{2}<0, \\
X_{i}^{\mathrm{d}} & =g\left(Y^{*} e, P X_{i}, P^{*} e\right), \quad g_{1}, g_{3}>0, \quad g_{2}<0, \\
I_{i}^{s} & =h\left[P I^{*}\left(1+S^{*}\right), P^{*}\right], \quad h_{1}>0, \quad h_{2}<0, \\
X_{i}^{s} & =j\left[P X_{i}\left(1+S_{i}\right), P_{i}\right], \quad j_{i}>0, \quad j_{2}<0, \\
P I_{i} & =P X^{*}\left(1+T_{i}\right) e,
\end{aligned}
$$

\footnotetext{
${ }^{8}$ The validity of the law of one price (net of transport costs and other impediments to trade) for these primary commodities is usually assumed rather than tested; see however McCloskey and Zecher (1976) who found support for it in price movement during the period 1870-1913.
} 


$$
\begin{aligned}
P I^{*} & =P X_{i}\left(1+T^{*}\right) / e, \\
I_{i}^{\mathrm{d}} & =I_{i}^{\mathrm{s}} e, \\
X_{i}^{\mathrm{d}} & =X_{i}^{\mathrm{s}} .
\end{aligned}
$$

These eight equations determine the quantity of imports demanded in country $i\left(I_{i}^{\mathrm{d}}\right)$, the quantity of country $i$ 's exports demanded by the rest of the world $\left(X_{i}^{\mathrm{d}}\right)$, the quantity of imports supplied to country $i$ from the rest of the world $\left(I_{i}^{s}\right),{ }^{9}$ the quantity of exports supplied from country $i$ to the rest of the world $\left(X_{i}^{s}\right)$, the domestic currency prices paid by importers in the two regions $\left(P I_{i}\right.$ and $\left.P I^{*}\right)$, and the domestic currency prices received by exporters in two regions $\left(P X_{i}, P X^{*}\right)$. The exogenous variables are the levels of nominal income in the two regions $\left(Y_{i}, Y^{*}\right)$, the price of (all) domestically produced goods in the two regions $\left(P_{i}, P^{*}\right)$, the proportional tariff $\left(T_{i}, T^{*}\right)$ and subsidy rates $\left(S_{i}, S^{*}\right)$ applied to imports and exports in the two regions, and the exchange rate $(e)$ linking the two currencies (expressed in units of country $i$ 's currency per unit of the rest-of-the world's currency).

The main characteristics of the imperfect substitutes model can be summarized as follows. In accordance with conventional demand theory, the consumer is postulated to maximize utility subject to a budget constraint. ${ }^{10}$ The resulting demand functions for imports and exports thus represent the quantity demanded as a function of the level of (money) income in the importing region, the imported good's own price, and the price of domestic substitutes. For aggregate imports or exports, the possibilities of inferior goods and of domestic complements for imports are typically excluded, so that income elasticities $\left(f_{1}\right.$ and $\left.g_{1}\right)$ and cross-price elasticities of demand $\left(f_{3}\right.$ and $\left.g_{3}\right)$ are assumed to be positive, ${ }^{11}$ whereas the own-price elasticities of demand $\left(f_{2}\right.$ and $\left.g_{2}\right)$ are of course expected to be negative. Most often, the additional assumption is made that the consumer has no money illusion,

\footnotetext{
${ }^{9}$ This is, of course, the supply of exports of the rest of the world to country $i$.

${ }^{10}$ When the importer is a producer and when imports are intermediate goods that are inputs to the domestic technology, the demand for imports can analogously be derived by maximizing production subject to the producer's cost constraint. In that case, the resulting import demand function will have as its arguments the price of imports, the price of the domestic (composite) input, and the level of domestic gross output; for example, see Burgess (1974), and Kohli (1982). ${ }^{11}$ Less assurance about the signs of the income elasticity and cross-price elasticities is warranted when the demand equations are disaggregated by commodity or by region of origin or destination of the trade flow; see Magee (1975, p. 179).
} 
so that a doubling of money income and all prices leaves demand constant, i.e. $f_{1}+f_{2}+f_{3}=0, g_{1}+g_{2}+g_{3}=0$. In its most common form, such homogeneity of the demand function is expressed by dividing the right-handside of eq. (1) by $P_{i}$ so that the two arguments of the demand function become the level of real income $\left(Y_{i} / P_{i}\right)$ and the relative price of imports $\left(P I_{i} / P_{i}\right)$. In this simple model, only current income matters for import (export) demand, and no distinction is made between secular or cyclical income movements or between transitory and permanent income. Also note from eqs. (5) and (6) that the price of imports relevant for import demand is the landed domesticcurrency price inclusive of all charges (tariffs, transportation, etc.) actually paid by the purchaser.

When we leave the two-country model for the $n$-country real world, the symmetry between the import demand eq. (1) and the export demand eq. (2) disappears. This is because a country's total imports face competition only from domestic producers, whereas a country's total exports face competition not only from domestic producers in the importing region but also from "third country" exporters to that region. Indeed, the conventional practice in specifying export demand equations is to assume that the dominant relative price competition occurs among exporters. Thus, the only relative-price term that typically appears is the ratio of the export price to competitors' export prices $\left(P X_{\mathrm{c}}\right)$ adjusted for exchange rate change, i.e. $\left(P X_{i} / P X_{c} \cdot e\right) .{ }^{12}$ In much of the empirical literature, the estimation of price effects on export demand has in fact been carried out within an "elasticity of substitution" framework. The demand equation then takes the form:

$$
X_{i}^{\mathrm{d}} / X^{\mathrm{d}^{*}}=v\left(P X_{i} / P X^{*} e\right), \quad v^{\prime}<0,
$$

where $X^{\mathrm{d} *}$ is the demand for exports to the rest of the world from third countries. One deficiency of eq. ( $\left.2^{\prime}\right)$ compared to eq. (2), especially as regards aggregate exports, is that the former implicitly assumes that the income elasticities of demand for exports from country $i$ and for those from third countries are the same in the rest of the world. ${ }^{13}$ As there is no a priori reason

\footnotetext{
${ }^{12}$ This restriction is often rationalized by the fact that industrial countries are their own principal competitors, so that $P X_{i} / P X_{c}$ and $P X_{i} / P_{i}$ will move together so long as domestic prices $(P)$ and export prices $(P X)$ are linked within countries.

${ }^{13}$ See Leamer and Stern (1970). For further analysis of the concept of "elasticity of substitution," see Richardson (1973).
} 
for this to hold, imposing such a restriction without first testing it is likely to involve some misspecification.

The specification of the two supply eqs. (3) and (4) are identical, with the quantity supplied assumed to be a positive function of the own price and a negative function of the price of domestic goods in the exporting country. Imposition of homogeneity on the supply function is equivalent to the restriction that $-h_{l}=h_{2}$ in eq. (3), and $-j_{1}=j_{2}$ in eq. (4). Although the theory of export supply is still very much a contested and unresolved subject in empirical trade work, the basic idea behind eqs. (3) and (4) is a simple one. The supply of exports will increase with the profitability of producing and selling exports. Therefore, the domestic price index $(P)$ serves a dual role in the supply functions. First, for a given level of the export price, the profitability of producing exports falls when factor costs in the export industries increase. As these factor costs are likely to move with the general level of domestic prices, $P$ serves as a proxy for them. Second, to the extent that resources involved in exportables production can be transferred to other uses or that the export price of a given good can be kept different from the domestic price, the relative profitability of selling exports falls with an increase in domestic prices. ${ }^{14}$ At the aggregate level, the domestic price index includes prices of tradable goods $(P T)$ sold at home as well as the price of nontradables $(P N T)$, i.e. $P=x P T+(1-x) P N T$, where $x$ is the weight of tradables in domestic consumption. Thus, the aggregate export supply functions (3) and (4) accommodate supply substitution between the home and export market for a given tradable good in the manner of the price-discriminating monopolist, as well as substitution between production of all tradables and nontradables.

Note that the relevant own price in the export supply functions is the price actually received by the exporter, inclusive of any subsidies $(S)$ or other incentives or penalties for exporting, and that the price is expressed in domestic currency terms. This latter seemingly innocuous point carries one significant implication. Even if the country is "small" in the sense that it cannot affect

\footnotetext{
${ }^{14}$ The model described by eqs. (1)-(8) does not really explain why domestic prices should not equal export prices. In the literature, the three main explanations for such a divergence are different demand elasticities in the home and export market, different cost structures for home and export production, or simply distortions in the market.
} 
the foreign currency prices of either its imports or its exports, it can still affect its export volume to the extent that it can affect the internal profitability of producing and/or selling exportables. For example, even in a situation where import demand is very price inelastic $\left(f_{2}, f_{3} \approx 0\right)$, where exports must carry the same foreign currency price everywhere $\left(P X_{i} / P X_{\mathrm{c}} e=1\right)$, and where the export price cannot be separated from the domestic price of tradables $(P X / P T=1)$, a devaluation can nevertheless have some potency (aside from expenditurereducing effects) via its impact on the internal terms of trade between exports and nontradables $(P X / P N T)$.

An advantage of presenting the supply side as well as the demand side of the imperfect substitutes model is to make it plain that the relationship between quantities and prices is, at least in theory, simultaneous. Despite this fundamental point, strongly emphasized in the trade literature of the 1950s [Orcutt (1950), Harberger (1953)], the bulk of the time-series work on import and export equations has addressed the supply side only by assumption. Specifically, the prevailing practice has been to assume that the supply-price elasticities for imports and exports [i.e. $h_{1}$ in eq. (3) and $j_{1}$ in eq. (4), respectively] are infinite. The great allure of such an assumption is that it permits satisfactory estimation of the import and export demand eqs. (1) and (2) by single-equation methods, since $P I_{i}$ and $P X_{i}$ can then be viewed as exogenous; conversely, if the supply elasticities are less than infinite, one should either estimate the full structural simultaneous model or solve for and estimate the reduced-form expressions for quantities and prices as functions of only the exogenous variables in the system. We shall have more to say on the simultaneity issue later. For now, it is sufficient to argue that the infinite supply-elasticity assumption is more defensible for a country's imports than for its exports. The rest of the world may well be able to increase its supply of exports to a single country without an increase in price, but it is less likely that even a large single country can increase its total export supply at a constant price unless there exists a large pool of unemployed resources in the export industry itself or elsewhere in the economy.

Our final comments on the imperfect substitutes model are caveats about the true "exogeneity" of at least one key exogenous variable (namely, domestic prices), about the legitimacy of an export supply function under conditions of less than perfect competition, and about the "equilibrium" or market-clearing property of the model. 
On the first point, there is by now a considerable body of empirical evidence [see Goldstein (1980), Kenen and Pack (1979), and Section 4] that suggests that domestic prices $\left(P_{i}\right)$, export prices in domestic currency terms $\left(P X_{i}\right)$ and money wages rates are each strongly influenced by exchange rate changes $(\Delta e)$ and by changes in foreign export prices $\left(\Delta P X^{*}\right)$, especially in small, highly-open economies with wage indexation schemes. The implication of such domestic price "feedback" effects, i.e. lack of exogeneity for $P_{i}$ in eqs. (1)-(4), is that high price elasticities offer no guarantee that devaluation or other expenditure-switching policies will actually be effective in altering a country's trade balance. ${ }^{15}$ If $P_{i}$ rises by close to, or equal to, the same proportion as $P I_{i}$ and $P X_{i}$ in eqs. (1) and (4) respectively, then the relative price changes induced by such policy actions will be small.

A second caveat is that export supply functions, like eqs. (3) and (4), can in theory exist independently of the demand functions only under conditions of perfect competition [Basevi (1973)]. Only under perfect competition is it legitimate to regard the export price as exogenous, that is as beyond the influence of the quantity supplied by any individual exporting country. For this reason, many trade researchers have chosen instead to work with reducedform export price equations where the quantity of exports does not appear at all. Following the empirical literature on domestic pricing under imperfect competition [e.g. Eckstein and Fromm (1968)], some such as Clark (1977) have assumed that the export price is set as a "markup" $(\lambda)$ on the level of normal unit labor cost $(Z),{ }^{16}$ with the size of the markup varying positively with the state of excess demand at home $\left(Y_{i} / \bar{Y}_{i}\right)$ and abroad $\left(Y^{*} / \bar{Y}^{*}\right)$, and with the level of competitors' export prices $\left(P X_{\mathrm{c}}\right)^{17}$ :

$$
P X_{i}=\lambda\left(Z, Y_{i} / \bar{Y}_{i}, Y^{*} / \bar{Y}^{*}, P X_{\mathrm{c}}\right), \quad \lambda_{1}, \lambda_{2}, \lambda_{3}, \lambda_{4}>0
$$

\footnotetext{
${ }^{15}$ We abstract here from the expenditure-reducing role of exchange rates or tariffs via their effect on the real value of money balances; on this latter role, see Frenkel and Johnson (1976).

${ }^{16}$ Normal unit labor cost is usually defined as the wage rate divided by the trend or normal level of real output per man hour.

${ }^{17}$ Another route is to derive the export price from the profit-maximizing conditions for a discriminating monopolist [see Artus (1977)]. The resulting estimating equation for $P X$, however, is usually quite similar to the one obtained from the markup model.
} 
Note that eq. $\left(4^{\prime}\right)$ has many similarities to the reduced-form equation that would emerge from solving the structural demand and supply eqs. (2) and (4) for $P X_{i}$ in terms of only the exogenous variables. This also explains why there has often been some confusion about whether the explanatory variables in export price equations like eq. $\left(4^{\prime}\right)$ represent supply or demand influences.

Turning to the equilibrium characteristic of the imperfect substitutes model as represented in eqs. (7) and (8), the implicit assumption is that prices move to equate supply and demand in each time period. This assumption, however, can be viewed as inconsistent with much of modern pricing theory, which argues that there are costs to changing prices in imperfectly competitive markets and that firms consequently will want to balance the costs of changing prices against the costs of other adjustment measures, such as changing inventories (stocks), unfilled orders (queues), and output itself [e.g. Hay (1970)]. ${ }^{18}$ This literature on "sticky prices" carries two suggestions for the specification of the imperfect substitutes trade model. One is that if the marketclearing property of the model is to be retained, then nonprice rationing variables should be included in both the demand and supply equations so that price changes alone are not responsible for market-clearing and the "full" or "effective" price actually faced by buyers and sellers governs demand and supply. ${ }^{19}$ A second alternative solution is to postulate that observed trade quantities and prices reflect markets in "disequilibrium" and accordingly, then to specify what the adjustment mechanisms are. For example, one can postulate that export prices respond to excess demand while export quantities respond to excess supply, or vice versa [Goldstein and Khan (1978)]; alternatively, one can argue that observed quantities and prices represent the lower of export demand or supply and then use recent econometric techniques [Fair and Kelejian (1974), Minford (1978)] to identify which observations correspond to periods of excess supply and which to excess demand. In short, the equilibrium characterization of the imperfect substitutes model is only one of several possibilities.

\footnotetext{
${ }^{18}$ Such price stickiness is regarded as a key factor in recent explanations of both exchange rate "overshooting" and the failure of purchasing power parity to work in the short run [see Dornbusch and Jaffee (1978)].

${ }^{19}$ By the "full" or "effective" price, we mean the observed price plus other implicit costs (e.g. waiting times, storage costs) paid by buyers and sellers.
} 


\subsection{The Perfect Substitutes Model}

Even though the imperfect substitutes model has been the mainstay of empirical work on trade equations, there are at least three reasons for examining the perfect substitutes model as well. First, despite many man-made impediments to arbitrage such as tariffs, quotas, and special preferential trading relationships, there is no denying that there are homogeneous commodities (wheat, copper, sugar, etc.) that are traded on organized international commodity markets at a common price (net of transportation and interest costs and expressed in terms of a common currency). For such "standard" commodities, a framework is needed where demands and supplies do not depend on price differentials between domestic and foreign goods. Second, it is possible that international differences in the methodology of constructing price statistics (e.g. weighting patterns, survey methods, index number formulae) can lead to observed international price differences for a given good or bundle of goods that understate the true degree of substitutability. In other words, some traded industrial goods may be closer substitutes than the (imperfect) price statistics would suggest. Third and finally, there may be insights about price and income elasticities for imports and exports that emerge from a perfect substitutes framework that do not when goods are assumed to be imperfect substitutes.

Equations (9)-(16) below constitute a simple perfect substitutes model of trade for our representative country $i$ :

$$
\begin{aligned}
D_{i} & =1\left(P_{i}, Y_{i}\right), \quad 1_{1}<0, \quad 1_{2}>0 \\
S_{i} & =n\left(P_{i}, F_{i}\right), \quad n_{1}>0, \quad n_{2}<0 \\
I_{i} & =D_{i}-S_{i}, \\
X_{i} & =S_{i}-D_{i}, \\
P I_{i} & =P_{i}=P X_{i}=e \cdot P_{\mathrm{w}}, \\
D_{\mathrm{w}} & =\sum_{i=1}^{m} D_{i}, \\
S_{\mathrm{w}} & =\sum_{i=1}^{m} S_{i}, \\
D_{\mathrm{w}} & =S_{\mathrm{w}} .
\end{aligned}
$$


In this perfect substitutes model, $D_{i}$ is the total quantity of traded goods demanded in country $i ; S_{i}$ is the supply of traded goods produced in country $i ; I_{i}$ and $X_{i}$ are the quantities of country $i$ 's imports and exports; $P I_{i}, P X_{i}, P_{i}$, and $P_{\mathrm{w}}$ are the import, export, domestic, and world prices of traded goods; $D_{\mathrm{w}}$ and $S_{\mathrm{w}}$ are the world demand and supply of traded goods; and $Y_{i}$ and $F_{i}$ are money income and factor costs in country $i$.

For the purposes of this chapter there are three main features of the perfect substitutes model. First, contrary to the imperfect substitutes model, there are no separate import demand or export supply functions. Instead, the demand for imports and the supply of exports represent the "excess" demand and "excess" supply respectively for domestic goods; see eqs. (11) and (12). This means that estimating or forecasting import demand or export supply for a perfectly substitutable good is really a matter of forecasting domestic demand and domestic supply, with imports or exports emerging as the residual. In practice, this often turns out to be more difficult than it sounds because estimates of domestic demand and supply elasticities are usually harder to obtain than those for imports or exports, and because the primary commodities that best fit the perfect substitutes mold are usually subject to "stock" as well as "flow" demand (with the former requiring specifications of price expectation schemes). Second, and again in contrast to the imperfect substitutes model, once we abstract from transportation costs and other trade barriers (e.g. tariffs) and express all prices in a common currency, then there is only one traded goods price in the perfect substitutes model (i.e. $P_{t}=P I_{i}=P X_{i}=P_{\mathrm{w}}$ ); furthermore, this (world) price is determined by the interaction of world supply and world demand for the traded good. ${ }^{20}$ Put in other words, country $i$ will only be able to affect the world price of the traded good to the extent that it can affect either world supply or world demand. In general, it can be shown [Isard (1977a), Clark (1977)] that in the absence of inventory and backlog changes, a country's ability to influence the world price of a homogeneous good will depend (positively) on both its share of world consumption (imports) and world production (exports) and on the value of its own price elasticities of

\footnotetext{
${ }^{20}$ Once nontraded goods are admitted, however, their prices (PNT) would enter the aggregate demand equation (9) with a positive sign. Similarly, once disaggregation is permitted, prices of "other" traded goods may enter the demand equation. Still, the essence of the model is that the same product, as long as it is freely traded, should carry the same price everywhere.
} 
demand and supply for that good. ${ }^{21}$ If the country is too "small" to affect the world price of the traded good, then an increase in domestic supply will reduce import demand directly (without any change in price). In contrast, the same increase in domestic supply in the imperfect substitutes model would reduce import demand via its effect on $P_{i}$ and hence on the relative price of imports, $P I_{i} / P_{i}$; see eq. (1).

Yet a third noteworthy feature of the perfect substitutes model is that it yields several implications for inter-country differences in price elasticities of supply and demand for imports and exports that do not emerge from the imperfect substitutes model. Specifically, using eqs. (12) and (13) and employing standard definitions of price elasticities of demand and supply, it is possible to relate the price elasticity of demand for imports $\left(\varepsilon_{I}^{\mathrm{d}}\right)$ and the price elasticity of supply for exports $\left(\varepsilon_{x}^{s}\right)$ to the domestic demand $\left(1_{1}<0\right)$ and supply-price elasticities $\left(n_{1}>0\right)$ of eqs. (9) and (10) as follows: ${ }^{22,23}$

$$
\begin{aligned}
\varepsilon_{I}^{\mathrm{d}} & =\frac{D_{i}}{I_{i}} \cdot 1_{1}-\frac{S_{i}}{I_{i}} n_{1}, \\
\varepsilon_{x}^{s} & =\frac{S_{i}}{X_{i}} n_{1}-\frac{D_{i}}{X_{i}} 1_{1} .
\end{aligned}
$$

Equation (17) states that the price elasticity of demand for imports $\left(\varepsilon_{I}^{\mathrm{d}}\right)$ of a homogeneous good will be positively related to the (absolute) values of the domestic demand and supply price elasticities, and negatively related to the shares of imports in domestic demand and in domestic production of the good. This proposition has often been advanced by "elasticity optimists" to support the claim that import price elasticities of demand can be high even for relatively inelastic products, and the more so the more closed the economy, namely when the ratios $I_{i} / D_{i}$ and $I_{i} / S_{i}$ are low. As noted by Magee (1975), at least the former implication of eq. (17) seems to be consistent with empirical evidence

\footnotetext{
${ }^{21}$ To see this, take the total differentials of eqs. (15) and (16), set $D_{\mathrm{w}}=S_{\mathrm{w}}$, and solve for $\mathrm{d} P_{\mathrm{w}}$. ${ }^{22}$ These derivations can be found in most international economics textbooks; for example, see Kreinin (1979).

${ }^{23}$ If an income term is added to the supply eq. (10), it is similarly possible to relate the income elasticity of demand for imports to income elasticities of demand and supply for domestic goods and to the shares of imports in domestic demand and in total supply; see Magee (1975, p. 189).
} 
in the sense that estimated import price elasticities of demand typically exceed estimated domestic price elasticities of demand. ${ }^{24}$

Turning to eq. (18), it similarly suggests that the export supply elasticity $\left(\varepsilon_{x}^{s}\right)$ will be positively related to the (absolute) value of the domestic demand price elasticity and negatively to the supply price elasticity and the shares of exports in domestic demand and in total supply of the good. Unfortunately, comparable estimates of domestic and export supply elasticities simply do not exist, so it is not possible to draw any conclusions as to whether the latter are larger than the former.

Finally, if we let the quantity of world exports $\left(X_{\mathrm{w}}\right)$ equal the sum of country $i$ 's exports $\left(X_{i}\right)$ and the exports of the rest of the world $\left(X^{*}\right)$, country $i$ 's export price elasticity of demand $\left(\varepsilon_{x}^{\mathrm{d}}\right)_{i}$ can be related to the export price elasticity of demand $\left(\varepsilon_{x}^{\mathrm{d}}\right)_{w}$ and to the export price elasticity of supply $\left(\varepsilon_{x}^{s}\right)^{*}$ in the rest of the world:

$$
\left(\varepsilon_{x}^{\mathrm{d}}\right)_{i}=\left(X_{w} / X_{i}\right)\left(\varepsilon_{x}^{\mathrm{d}}\right)_{w}-\left(X^{*} / X_{i}\right)\left(\varepsilon_{x}^{s}\right)^{*}
$$

The implication of eq. (19) is again on the side of the "elasticity optimists", for even if the global export price elasticity of demand for a homogeneous good is relatively small, a single country's export price elasticity of demand can be high if it has a small share in world exports. Note, however, that if one views eqs. (17), (18) and (19) as a group, then a country cannot simultaneously have (relatively) large demand price elasticities for imports and exports and a large supply price elasticity for exports unless it is both relatively closed to imports and exports and maintains a relatively small share of world exports. ${ }^{25}$ The United States, for example, would meet the first criterion but not the second, while the smaller European countries such as Belgium and the Netherlands would meet the second criterion but not the first.

\subsection{Choice of Variables}

With the general outlines of the imperfect and perfect substitutes models in mind, we next consider the empirical variables that have been used as the

\footnotetext{
${ }^{24}$ Compare the domestic price elasticities of demand in Houthakker and Taylor (1970) with the import price elasticities for the United States in Houthakker and Magee (1969), Stern et al. (1976), and Clark (1977).

${ }^{25}$ The question of inter-country differences in price and income elasticities is discussed at greater length in Section 4.
} 
appropriate counterparts to the theoretical ones. The discussion is selective rather than exhaustive, concentrating upon what we regard as the most important issues.

\subsubsection{Dependent variables}

As indicated earlier, conventional trade models, like the demand and production theories on which they are based, treat import (export) quantities or prices but not their product as the dependent variables. Trade data, however, are oblivious to this theoretical nicety and are most readily available in value terms. This means that an appropriate deflator has to be found to convert the value data back into its quantity and price components. This problem takes on considerable difficulty and complexity when dealing with the large number of products that comprise a country's aggregate imports and exports. One encounters all the usual problems associated with constructing price indices, namely those related to current or base period weights, quality change, changing composition of products within broader goods categories, etc. along with the additional requirement of reasonable comparability across countries.

The best deflator would of course be the actual transactions or contractual prices for imports $(P I)$ and exports $(P X)$ themselves. Indices based on such international transactions prices do exist but their country, product, and timeperiod coverage are as yet quite limited. ${ }^{26}$ In brief, these price data are restricted to only a few major industrial countries, the time-series seldom extends beyond a ten year period, only some manufactured goods are included, and exports are much better represented than imports.

Faced with the absence of comprehensive data on $P I$ and $P X$, empirical trade researchers have relied on two second-best but more widely available price deflators, namely unit value indices (PUV) and wholesale price

\footnotetext{
${ }^{26}$ The NBER export price series constructed by Kravis and Lipsey (1971, 1974, 1978) cover machinery, transport equipment, metals, and metal products for the time periods 1957-53, 1961-57, 1962-61, 1963-62, and 1964-63. The indices were calculated for the United States, the United Kingdom, Germany, and on a more partial basis for Japan and the Common Market as a whole. Official export price series are also produced by Germany and Japan, but Kravis and Lipsey (1974) raise some doubts about their quality. Finally, trade price indices for the United States have recently become available [Bureau of Labor Statistics (1980)] for some manufactured products over the 1970-79 period.
} 
indices $(P W H) .{ }^{27}$ Unit value indices are calculated by dividing the value of imports (exports) by the physical quantities of imports (exports). While perfectly legitimate for a single product, this procedure yields spurious price indices when quite different products are combined in one index. For example, when the commodity composition of imports changes, a unit value index will change even if all "true" prices of the component import products remain unchanged. Similarly, because unit value indices are not fixed-weight indices, a price increase accompanied by a decrease in quantity demanded automatically lowers that good's weight in the index. Wholesale prices escape this latter problem but include some goods often regarded as nontradables, use domestic rather than international weights for the tradable goods, and refer to list rather than transaction prices. ${ }^{28}$ Also, as suggested earlier, the domestic and export price for a given product can diverge for nontrivial time periods reflecting various types of market imperfections.

If $P W H$ and $P U V$ are conceded to have drawbacks as representations of true import and export prices, how significant are these drawbacks likely to be? Kravis and Lipsey (1974) have provided some answers to this question by comparing movements of $P W H$ and of $P U V$ with their series on international transactions prices for manufactured exports $(P X)$. In short, they found that: (i) there was a statistically significant positive relationship between $P X$ and $P W H$ and between $P X$ and $P U V$ but that this relationship was considerably closer $\left(R^{2}=0.47\right)$ in the first case than in the second $\left(R^{2}=0.06\right)$; (ii) the relationship between $P X$ and $P W H$ was much closer for some countries (the United States, the United Kingdom), than for others (Germany, Japan); and (iii) the relationship between $P X$ and $P W H$ was not noticeably closer for time spans longer than one year than for one-year periods.

A related but perhaps more central question for this chapter is how poor measures of $P I$ and $P X$ will affect the estimated price elasticities of demand and supply. Two cases need to be distinguished. The first case is where the dependent variable $(I$ or $X)$ is correctly measured but there is

${ }^{27}$ Unit value indices are published in the IMF's International Financial Statistics (IFS) for practically all IMF member countries. They typically extend back to the early 1950 s, and cover total imports and total exports. The coverage and availability of domestic wholesale price indices are similar to those of unit value indices.

${ }^{28}$ The consumer price index and the gross domestic product deflator also have serious deficiencies as proxies for traded goods prices; see Goldstein and Officer (1979). 
measurement error in the import or export price data. In this situation, we have a standard errors in variables problem [Kmenta (1971)], and we get the standard results, namely, the estimated coefficient on $P I$ or $P X$ will be biased toward zero. ${ }^{29}$ Consistent with this diagnosis, Kravis and Lipsey (1974) found that replacement of $P W H$ with $P X$ in a conventional export elasticity-ofsubstitution equation [like eq. $\left(2^{\prime}\right)$ above] led to estimated elasticities that were roughly twice as high, as well as to significantly higher explanatory power for the equation itself. The second case, which is probably the predominant one in practice, is where an improperly measured $P I$ or $P X$ series is used to deflate an error-free import or export value variable, as well as for the explanatory price variable. Here, negative correlation will be introduced between the errors in the dependent variable and the errors in the explanatory price variable, with the result that the estimated price elasticity will be biased toward minus one [Kemp (1962a), Kravis and Lipsey (1974), Magee (1975)]. It therefore suggests some suspicion of unitary price elasticity estimates from studies where both the dependent and independent variables are derived using PWH or PUV.

The next relevant question is what options are available to the empirical trade researcher facing poor import and export price data. At one extreme, trade equations can be specified with the value of imports (exports) as the dependent variable [e.g. Branson (1968)]. Since the volume price elasticity of demand is equal to the value elasticity minus one, this procedure still permits estimation of the former. Also, if the purpose of the exercise is to estimate or forecast only the value of imports, this procedure has obvious advantages over trying to explain two component series of poor quality. Its main disadvantage is that the determinants of price and volume are different, and a single equation therefore carries the danger that the estimated coefficients will represent some unknown interaction of supply and demand influences. At the other end of the spectrum, one can work with the widely available price proxies ( $P U V, P W H$ ), accept the danger of biased estimates, and exercise due caution on the ranges of the true elasticities. This has been the route followed in the most of the studies on total imports (exports) simply because the better quality export or import price data are not available at high levels of aggregation; also, some researchers [Beenstock and Minford (1976)] have

\footnotetext{
${ }^{29}$ This was one of the arguments used by Orcutt (1950) to support his position that true price elasticities of demand for imports exceeded the estimated ones.
} 
argued that component measurement errors may at least partially cancel out at high levels of aggregation. Intermediate options include restricting hypothesistesting on demand and supply elasticities to goods for which the better quality price data are available [e.g. Artus and Sosa (1978)]; replacing import unit values with a weighted index of exporters' domestic wholesale prices [e.g. Clark (1977)]; relaxing the homogeneity restriction on relative import (export) prices as a concrete response to the larger assumed measurement error in import or export prices than in either the domestic price index or the exchange rate [e.g. Ahluwalia and Hernandez-Cata (1975)]; and using the exchange rate and the tariff rate to generate the local-currency price of imports as a substitute for the unit value index [e.g. Mutti (1977)].

\subsubsection{Income and other scale variables}

In our exposition of the imperfect substitutes model, the demands for imports and exports were treated as positive functions of the level of real income in the importing regions. While this has overwhelmingly been the conventional practice in empirical work, alternative and/or additional "scale" variables have frequently been proposed for both aggregate and disaggregated demand functions. In addition, scale variables have also found their way into the export supply function.

\subsubsection{Import demand}

There are at least three conscious choices to be made in the specification of the scale variable in the aggregate import demand equation ${ }^{30}$ : (i) should one use

\footnotetext{
${ }^{30}$ When the dependent variable in the import demand function is disaggregated by type of commodity, prevailing practice is to make an accommodating disaggregation adjustment in the scale variable so as to get a better fix on the particular component of aggregate income or expenditure that shifts the demand for that commodity. For example, Deppler and Ripley (1978) use real consumption expenditure as the scale variable in the import volume equation for foods and beverages, an average of output in manufacturing and real final domestic demand for manufactures in the equation for manufactures, etc. If the existing disaggregated import functions can be criticized it is not for failing to select an appropriate scale variable for a particular type of imports but rather for doing only that. Thus, import demand functions for primary products seldom distinguish between flow and stock demand; functions for investment goods make little effort to model expected output or to specify longer lag structures appropriate to capital goods; import functions for durable goods typically find no place for habit formation, etc. For discussion and estimates of disaggregated trade equations, see Kreinin (1967), Stone (1979), Deppler and Ripley (1978), and Rhomberg and Boissonneault (1965).
} 
real income or real expenditure; (ii) if real income is chosen, should cyclical and secular movements in real income be treated separately; and (iii) how should "life-cycle" or "permanent/transitory" consumption patterns be handled in import demand.

(i) Real income versus real expenditure. The issue here is whether domestic demand for foreign goods (imports) should properly be related to domestic demand for all goods, i.e. to expenditure, or rather to the sum of domestic demand for domestic goods and the foreign demand for domestic goods (exports), i.e. to income. Micro demand theory offers little guidance since it typically constrains expenditure to equal income. In the empirical literature, the choice between these two scale variables has usually been made on grounds of consistency with the implicit or explicit overall model of balance-of-payments adjustment. Specifically, real expenditure has been favored in a monetary-oriented framework because it can be related to the difference between actual and real money balances, thereby assuring a direct role for money in trade and balance-of-payments adjustment [see, for example, Aghevli and Khan (1980)]. In contrast, the Keynesian preference for real income follows naturally from the foreign-trade multiplier, income-driven view of balance-of-payments adjustment. ${ }^{31}$ Rather surprisingly, there has been practically no attempt to choose between these two alternative scale variables on empirical grounds (e.g. goodness-of-fit criterion). ${ }^{32}$

(ii) Secular versus cyclical real income. In our prototype import demand eq. (1), movements in real income $\left(Y_{i} / P_{i}\right)$ were assumed to have the same effect on the quantity of imports demanded regardless of whether these movements represented trend (secular) or cyclical variations about that trend. This assumption has been challenged in empirical work. First, there is the argument alluded to earlier, that prices do not act to clear markets, especially during periods of excess demand. Instead, periods of excess demand are said to be characterized by longer domestic waiting times, less availability and

\footnotetext{
${ }^{31}$ Prevailing practice treats the monetary and Keynesian (cum elasticity) models of balance-ofpayments adjustment as alternatives, but they can clearly be reconciled in a more general model of balance-of-payments adjustment.

${ }^{32}$ An exception is the study by Brillembourg (1975) for three Latin American countries Colombia, Ecuador, and Venezuela. He found that real expenditure, along with relative prices and quantitative rationing variables, produced a better explanation of import demand than did an analogous specification using real income.
} 
higher costs of credit, and less vigorous pursuit of new orders by suppliers - a consequence of which is that consumers increasingly turn to foreign suppliers [Gregory (1971)]. For these reasons, the cyclical income elasticity of demand for imports is expected to exceed the secular elasticity. The second challenge, which complements the first one, is that the secular income elasticity of demand for imports is best viewed within a perfect substitutes framework as equal to the difference between the domestic production and consumption of importables [Johnson (1958), Magee (1975)]. This suggests not only that the secular elasticity may be less than the cyclical income elasticity but also that the secular elasticity might even be negative under certain conditions. 33

Our reading of the empirical evidence on cyclical versus secular income elasticities can be summarized as follows. First, when trend (or potential) real income and cyclical real income are included in the import demand equation at the same time, both usually appear with positive and statistically significant coefficients [Clark (1977), Lawrence (1978)]; the same verdict applies to import demand equations where real income and capacity utilization appear jointly [Branson (1968), Hooper $(1976,1978)]$. Second, there is some tendency for the estimated cyclical elasticities to exceed the secular elasticities [Deppler and Ripley (1978)], but there are enough exceptions [Khan and Ross (1975), Geraci and Prewo (1980)] to cast serious doubt on the final outcome. Third, since Magee's (1975) reluctant conclusion that he could not find any negative estimates of secular income elasticities for total imports, some have appeared [e.g. Khan and Ross (1975)], but it is by no means clear how these should be interpreted since they presumably mix together import substitution, tastes, and other structural factors. Fourth, if one grants the case that nonprice rationing of imports occurs during cyclical upswings, it is still an open question as to whether cyclical income variables are the best way to measure these effects [e.g. Gregory (1971) prefers estimated waiting times as a rationing proxy]. Fifth, more recent studies [e.g. Hooper $(1976,1978)]$ have moved in the desirable direction of including cyclical income abroad as well as

\footnotetext{
${ }^{33}$ As indicated in Magee (1975, p. 189), the condition for a negative income elasticity is $(D I / S I)<\left(E_{Y}^{\mathrm{s}} / E_{Y}^{\mathrm{d}}\right)$, where $E_{Y}^{\mathrm{s}}$ and $E_{Y}^{\mathrm{d}}$ are the domestic income elasticities of supply and demand respectively, and $D I$ and $S I$ are the domestic demand for and supply of importables, respectively.
} 
at home in the demand equation to capture relative nonprice rationing costs. If prices do not clear markets at home, they probably do not abroad either.

(iii) Permanent and transitory income. As is well known, the distinction between current income and "permanent" or "life-cycle income" is at the core of modern consumption theory [see Dornbusch and Fisher (1978) for a lucid summary]. Since imports represent consumption by domestic residents of foreign goods, it is surprising that so little attention has been given to this distinction in the specification of the aggregate import demand function. ${ }^{34}$

Potential application of permanent income or life-cycle concepts to the aggregate import demand function raises the following points and puzzles. To begin, one motivation for the permanent income and life-cycle models was to explain the greater slope of the long-run consumption function in the United States, compared to the short-run function. As indicated earlier, however, most empirical trade studies find a higher income elasticity for imports from cyclical income than from potential or trend income. This suggests that cyclical non-price rationing effects predominate over permanent/transitory consumption differences. Second, it needs to be acknowledged that the key operational problem central to testing of both the permanent and lifecycle income hypotheses - how best to relate expected future income to current and past observed income - still seems to be unresolved in the literature. In addition to the econometric problems associated with generating permanent income via use of fixed distributed lags [see Lucas (1976)], there is the additional problem in import functions that one may not want to impose the same lag distribution on all the explanatory variables. ${ }^{35}$ Third,

\footnotetext{
${ }^{34}$ A notable exception is the recent study by Geraci and Prewo (1980) where cyclical and trend components of real income are given transitory and permanent income interpretations and where the estimated permanent income elasticity exceeds the transitory income elasticity in four out of the five sample countries. Also, note that the case for making permanent/transitory income distinctions does not apply to "separable" or "allocative" import functions where the decision of how much to consume is treated separately from the decision of how to allocate total consumption between imports and domestic goods.

${ }^{35}$ Hall (1978) has offered a way around these problems by proposing tests of the permanent income and life-cycle models that concede from the outset that none of the right-hand-side variables is exogenous; specifically, the test involves determining whether all variables other than consumption lagged one period have nonzero coefficients in a regression equation for current consumption. The rub is that this approach may reveal little about the true structural relation between consumption and its determinants.
} 
and operating in the opposite direction, the joint finding that only current income is usually significant in import demand functions and that there is an apparent structural instability in the behavior of income elasticities of demand for imports [Hooper (1978), Stern et al. (1979)] is suggestive of some payoff from trying alternative representations of real income. Similarly, one can note the considerable measure of success achieved by Sachs (1981) in using an inter-temporal life-cycle savings/investment framework to explain the pattern of current account positions after the oil shocks of the 1970s. In sum, there would seem to be plenty of room and reason for experimenting with other specifications of real income in the aggregate import demand function to bring it closer into line with the treatment of aggregate consumption in the domestic empirical literature.

\subsubsection{Export supply}

The application of income and other scale variables in work on export supply (or pricing) has been less intensive, but two issues merit discussion: (i) the roles of trend income and trend exports in export supply, and (ii) the effects of cyclical income or demand changes on the supply of exports.

(i) Trend income. The basic argument for including trend income in the export supply function is that a country or industry's ability and willingness to supply exports will not be fully captured by the ratio of export prices to domestic prices (or factor costs) but will depend also on the output capacity of the economy as a whole. Put in other words, secular changes in the level of aggregate real output will be accompanied by advances in factor supplies, infrastructure, and total factor productivity that will lead to an increase in export supply at any given level of export prices. When such a trend output variable has been added to a conventional total export supply function [like eq. (4)], the results have been encouraging. Goldstein and Khan (1978) found that trend income appeared with the expected positive sign and was statistically significant in their equations for total exports in all eight industrial countries in their sample. Similarly, Geraci and Prewo (1980) found a significant positive effect for potential output in all five of their country export-supply equations.

(ii) Trend exports. This is a variable that has not been considered in the empirical export-supply literature but one that should be if export supply functions are to be compatible with some of the recent theoretical literature 
on aggregate supply. At the center of this new neoclassical supply literature [see Lucas (1973), Sargent (1976)] is the so-called "surprise" supply function. The basic idea is that actual supply $(Y)$ will exceed normal or trend supply $(\bar{Y})$ only to the extent that current price $(P)$ exceeds the expected price $\left(P^{\mathrm{e}}\right) .{ }^{36}$

Application of the "surprise" supply function to exports is attractive for at least three reasons. First, it does not stretch the imagination unduly to think of the domestic price as a reasonable measure of the expected export price. Exporters know from experience that there will be temporary periods for which export prices will depart from domestic prices, but $P X=P_{i}$ in the long run and on average; hence $P_{i}$ can serve as good predictor of $P X .^{37}$ Second, when $P^{\mathrm{e}}=P$ (i.e. $P=P X$ ), where $P^{\mathrm{e}}$ is the expected price level, then the surprise supply function implies that actual (current) export supply will equal trend exports. This seems preferable to the implication of the standard supply function (4) that export supply will be constant when $P X=P$. Third, if trend exports and trend real output move closely together, then those empirical results that find a significant positive role for trend output in total export supply would likewise be consistent with a positive significant role for trend exports. In any case, this strikes us as a promising area for future research.

(iii) Cyclical income effects. Most of the empirical work in this area is based on the twin premises that when domestic demand pressure increases, selling in the home market becomes more profitable than selling abroad, and that this increased profitability is not fully captured by movements in the ratio of domestic to export prices. This cyclical tilt toward the domestic market might reflect the better quality of domestic customers (e.g. larger purchase volume, stronger brand allegiance) or a perceived higher risk associated with export sales. In any event, the prediction is that the quantity of resources devoted to export production and the quantity of goods offered to the export market will decline when domestic income rises above trend. Operationally, the implication is that a cyclical income or other scale variable ought to be added to the export supply equation.

\footnotetext{
${ }^{36} \mathrm{~A}$ stochastic (error) term is usually included in the supply function, but it need not concern us here.

${ }^{37}$ In cases where the data contradict the hypothesis that $P X=P$ on average, one could still retain the surprise supply function by: (i) using a time-series model to generate the "expected" ratio of $P X$ to $P$; (ii) by using deviation of the actual from the expected ratio to measure "surprises" in relative export prices; and (iii) by relating export quantity surprises to relative export price surprises.
} 
Review of the existing empirical evidence on the export supply effects of domestic demand pressure prompts the following conclusions and observations. First, Mintz's (1967) finding, based on non-econometric tests for the United States, that cyclical upturns are associated with decreases in export quantities and increases in export prices has been supported by later econometric studies for the United States and other industrial countries [Artus (1973) (1977), Clark (1977), Hooper (1976) (1978), Winters (1976), Dunlevy (1979)]. Second, no consensus has yet emerged on whether the positive export price effect of domestic demand expansions is larger or smaller than the negative export quantity effect. Ballpark estimates are that a 10 percent increase in the capacity utilization rate would in the long run reduce the quantity of exports supplied by 3-5 percent [Artus (1973), Dunlevy (1979)] and increase the export price by a similar percentage [Artus (1977)]; there are wide inter-country differences, however, around these central quantity and price elasticities. Third, one of the main channels by which domestic demand pressure reduces the quantity of exports is via the former's effect on lengthening delivery delays and hence on weakening the exporting country's nonprice competitive position [Ball et al. (1966), Artus (1973)]; this is sometimes referred to as the "pull" effect of domestic demand pressure and it suggests that domestic cyclical income variables play a role in the foreign demand for exports as well.

\subsubsection{Relative prices}

Whereas the choice for scale variables is usually which one among many to pick, the problem for relative prices is rather which ones to exclude so as to keep the number of price terms small enough for estimation purposes while still capturing the dominant sources of demand or supply substitution.

\subsubsection{Aggregate import demand}

A country's total imports face potential competition from two broad categories of domestically produced goods, namely tradables and nontradables. ${ }^{38}$ This means that an unrestricted demand equation for imports would have three prices - import prices $\left(P I_{i}\right)$, domestic tradable prices $\left(P T_{i}\right)$ and domestic

\footnotetext{
${ }^{38}$ If exports and domestic tradables carry different prices, then exports constitute a third separate source of competition for imports.
} 
nontradable prices $\left(P N T_{i}\right)$. In the empirical literature, the typical practice has been to assume that the demand for imports is independent of the price of nontradables, and the rationale is that the consumer engages in a two-step decision process. In step one, he allocates his expenditure between all tradable and nontradable goods on the basis on his income and the relative price of tradables to nontradables. In the second step, he allocates his expenditure on tradable goods (given at step one) between imports and domestic tradables. By virtue of such "separability" in consumption, only one relative price namely that between imports and domestic tradables - need appear in the import demand equation. PNT is relevant therefore only for the demand for all tradables. In short, combining such separability with homogeneity, the import demand function takes the form

$$
I_{i}^{\mathrm{d}}=\gamma\left(Y_{i} / P T_{i}, P I_{i} / P T_{i}\right), \quad \gamma_{1}^{\prime}>0, \quad \gamma_{2}^{\prime}<0 .
$$

The problem is that when the researcher moves to estimate eq. $\left(1^{\prime}\right)$, he immediately faces the problem that price indices for domestic tradables as such do not exist. Conventional procedure is therefore to use one of two readily available proxies, namely the wholesale price index $(P W H)$ or the implicit deflator of gross domestic product $(P G D P)$. However, both these indices contain nontrivial shares of products that might reasonably be considered as nontradables [Goldstein and Officer (1979)]. The consequence is that, in actual estimation of eq. $\left(1^{\prime}\right)$, the cross-price elasticity of demand for imports is constrained to be identical as between domestic tradable and nontradable goods. Thus, the PNT that was excluded by theory comes in by the back door of data availability.

Goldstein et al. [1980], using price indices for tradable and nontradable goods constructed from data on current and constant dollar GDP by industry of origin, ${ }^{39}$ found that the price of nontradable goods was not a significant determinant of the demand for total imports in the majority of industrial countries in their sample. This finding supports the "separability" assumption typically made in aggregate import demand studies. Second, both Goldstein et al. (1980) and Murray and Ginman (1976), the latter working only with

\footnotetext{
${ }^{39}$ The tradable sector consists of agriculture, mining, and manufacturing. All other industries in which GDP originates are classified as nontradables; see Goldstein and Officer (1979) for a more detailed discussion of this data base on tradable/nontradable prices and real output.
} 
U.S. data, report that the cross-price elasticity of demand for imports is higher, as expected, with respect to the price of domestic tradables than the price of nontradables.

Similarly, the estimated price elasticities of demand for imports generally turn out to be larger and more significant when the price of tradables is used as the denominator of the relative price variable than when a general domestic price index inclusive of nontradables $(P G D P)$ is employed. ${ }^{40}$

\subsubsection{Disaggregated import demand}

Once imports or exports are disaggregated by type of commodity and/or by country of origin or destination, the number of potential competitors for imports of type $i$ from country $j$ increases dramatically. Therefore, some more systematic and explicit scheme has to be adopted to permit estimation or derivation of the own-and cross-price elasticities of demand.

The most popular solution to this problem, reflected in most recent world trade models [Samuelson (1973), Hickman and Lau (1973), Deppler and Ripley (1978), Artus and McGuirk (1981), Geraci and Prewo (1980)], is due to a pioneering contribution by Armington (1969). The building blocks of the Armington model can be summarized as follows. ${ }^{41}$

First, all commodities are distinguished by kind and by place of production. Types of commodities (called "goods") correspond to rather broad commodity classifications, such as nontradables, manufactures, raw materials, etc. Goods produced by different countries are called "products". Thus French and German manufactures are the same good but are different products. Products are assumed to be imperfect substitutes for one another.

\footnotetext{
${ }^{40}$ Turning from the domestic to the import price, it is important to note that tariffs should be included in the domestic-currency price of imports. Unhappily, inclusion of tariff rates is still the exception rather than the rule in the empirical literature, despite the fact that the average ad-valorem tariff on industrial-country imports has been changing (falling) over the past few decades [IBRD (1981)] and the evidence [e.g. Kreinin (1961)] that tariff changes do have sizeable effects on import demand. Quantitative restrictions on imports should similarly be taken into account in import demand although there is no obvious method of measuring them. See Brillembourg (1975), Khan (1974), Hemphill (1974), and Weisskoff (1979) for alternative approaches to measuring the effect of price and quantity restrictions on imports.

${ }^{41}$ Our description of the Armington model follows Branson (1972), Rhomberg (1973), and Artus and McGuirk (1981), but in a much more condensed form.
} 
Second, the import demand for a product is determined in a "separable" two-step manner. In step one, the consumer determines his demand for the goods family to which a product belongs on the basis of his income, the good's price, and the prices of other goods. In step two, he determines his demand for that product on the basis of his overall demand for that good (given at step one) and of the ratio of the product's price to the weighted average of the prices of other products in that same goods family.

Third, by assuming that the elasticities of substitution between all pairs of products in the same goods family are identical and constant in any market, it is possible to characterize the allocative or distribution function in step two as

$$
I_{1 i j}^{\mathrm{d}} / I_{1 i}^{\mathrm{d}}=b_{i j}^{\phi_{i j}}\left(P_{1 i j} / P_{1 i}\right)^{-\phi_{i j}},
$$

where $I_{1 i j}^{\mathrm{d}}$ is the quantity of imports demanded in country $i$ of good 1 exported by country $j$ (that is of product $i j$ ) $I_{1 i}^{\mathrm{d}}$ is the quantity of good 1 demanded in country $i$ from all sources of supply, $b_{i j}$ is the base period quantity share of country $j$ in total imports of good 1 by country $i, P_{i j}$ is the price of product $i j, P_{1 i}$ is the price of good 1 in country $i$ (equal to a weighted average of product prices within good 1 ), and $\phi_{i j}$ is the elasticity of substitution for product $i j$.

Fourth, and most important, this framework permits the derivation of formulae for both the direct $\left(d_{i j}\right)$ and cross price $\left(c_{i j}\right)$ elasticities of demand for imports of any product into country $i$ from any exporting country $j$ using only three pieces of information: (i) the share of each exporter in the importing country's total demand for that good $\left(S_{i j}\right)$; (ii) the elasticity of substitution for products within that goods family $\left(\phi_{i j}\right)$; and (iii) the own-price elasticity of demand in the importing country for that good $\left(n_{i 1}\right) .{ }^{42}$ Trade share parameters $\left(S_{i j}\right.$ 's) can be readily obtained from published OECD or IMF sources on the direction of trade. The elasticities of substitution $\left(\phi_{i j}\right)$ and price elasticities of demand $\left(n_{1 j}\right)$ are less straightforward to acquire but usual practice is to base them on available published studies.

The Armington methodology has at least three appealing features. It provides an extremely economical and consistent method for estimating

${ }^{42}$ Following Branson (1972, p. 29$)$, the direct $\left(d_{i j}\right)$ and cross-price elasticities of demand $\left(c_{i j}\right)$ by country $i$ for product $i j$ can be expressed as:

$$
\begin{aligned}
d_{i j} & =-\left[\phi_{i j}-S_{i j}\left(\phi_{i j}-n_{i 1}\right)\right], \\
c_{i j} & =S_{i j}\left(\phi_{i j}-n_{i 1}\right) .
\end{aligned}
$$


all the bilateral and multilateral direct and cross-price effects of a single or simultaneous set of traded goods price changes. For this reason, the methodology has been extensively used to estimate the trade balance effects of a hypothetical or actual set of currency realignments [Armington (1970), Branson (1972), Artus and Rhomberg (1973), Artus and McGuirk (1981)]. Furthermore, the methodology itself is quite flexible, as evidenced by its subsequent application to export supply functions [Geraci and Prewo (1980)] and to trade in intermediate goods [Clements and Theil (1978)]. Finally, the model yields some interesting implications for intercountry differences in price elasticities. Specifically, in the usual case when the elasticity of substitution $\left(\phi_{i j}\right)$ is larger in absolute value than the price elasticity of demand for the respective goods class $\left(n_{1 i}\right)$, the model implies that countries with larger market shares should have a relatively low own-price elasticities of demand for their goods and a relatively high cross-price elasticities of demand [Branson (1972), Tables 4 and 5, and eqs. (20a) and (20b)]. The rationale is that if a country has a small market share, a decrease in its relative price increases its sales principally by taking away business from other exporters; but if it already has a major share of the market, price declines increase its sales only if the size of the market itself grows.

At the same time, it is also clear that the Armington model is not without problems. One is in choosing the right level of aggregation for the goods categories. If these are defined too narrowly, the separability assumption is likely to be violated; if they are very broadly defined, the assumptions governing estimates of the elasticity of substitution (i.e. identical income elasticities) are likely to be violated. Another caveat is that the Armington model is just a methodology for computing direct and cross-price elasticities of demand, and the estimates derived from it will only be as good as the estimates of $\phi_{i j}$ and $n_{1 i}$ on which the former are based. Estimates of elasticities of substitution abound in the literature, but much less is known about the price elasticities for broad goods classes.

\section{ECONOMETRIC ISSUES IN TRADE MODELLING}

In proceeding from the theoretical models outlined in the previous section to actual estimation of trade relationships, several important econometric issues have to be addressed. The particular issues we consider in this section are: 
dynamics and the treatment of lags, aggregation, simultaneity, and the stability of the relationships over time. ${ }^{43}$ While this list by no means exhausts all the econometric issues, it nevertheless covers the major ones. Careful attention to these issues is a prerequisite for doing quantitative work on the subject. ${ }^{44}$

For expositional convenience, the analysis here is conducted only for the case of the import demand function. It is a simple matter to translate the discussion to the case of export demand, and in general to the supply functions for imports and exports as well. Specific issues relating to the latter are dealt with separately as the analysis requires.

\subsection{Dynamics and Time Lags}

Thus far, the basic demand and supply equations for imports and exports have been presented as "equilibrium" relationships, without any reference to time units. In the real world, however, the presence of adjustment costs and of incomplete information implies that the adjustment of dependent variables to explanatory ones will not be instantaneous, i.e. importers and exporters will not always be on their long-run demand and supply schedules. Gauging the pattern and length of such time lags is important not only for obtaining

\footnotetext{
${ }^{43}$ Two particular issues which we do not cover here are homogeneity and the appropriate functional form of the estimating equation. The subject of homogeneity of demand and supply equations has been discussed by Leamer and Stern (1970) and tests of the postulate that the functions are homogeneous of degree zero in prices have been performed by Murray and Ginman (1976), Mutti (1977), and Goldstein et al. (1980), among others. In the last study, it is shown that the homogeneity postulate is generally accepted for import demand equations of most industrial countries. Insofar as the functional form is concerned, Khan and Ross (1977) provide a description of the Box and Cox (1964) methodology that can be used to determine empirically whether the function should be specified in linear or log-linear terms, and further show that log-linear specification is preferable for import demand equations in the cases of Canada, Japan and the United States. This finding was confirmed by Boylan, Cuddy, and O'Muircheartaigh (1980) for three smaller European countries — Ireland, Denmark and Belgium. An interesting recent paper by Honda and Ohtani (1980) jointly tests for homogeneity and the appropriate functional form by generalizing the procedure adopted by Khan and Ross (1977).

${ }^{44}$ It is probably fair to argue that researchers in the international trade sphere have been more conscious of econometric problems and pitfalls than those in most other areas of applied economics. This sensitivity can be traced back to the seminal paper of Orcutt (1950) which highlighted the various methodological issues involved in estimating import and export equations, and which still serves as a continuing guide and conscience to anyone engaged in empirical research on trade.
} 
forecasts of imports and exports but also for evaluating many policy issues related, for example, to changes in tariffs, exchange rates, and so on.

What is at issue, then, is not whether lags ought to be incorporated in trade equations but rather how best to do so. A simple approach to the modelling of dynamic trade behavior is to specify the equation within the framework of a general distributed-lag model with geometrically declining weights. This has come to be known popularly as the "Koyck" model, which for the specific case of import demand is written as: ${ }^{45}$

$$
I_{t}=\beta \sum_{j=0}^{\infty}(1-\beta)^{j} I_{t-j}^{\mathrm{d}} .
$$

The parameter $\beta$ measures the response of actual imports to the demand for imports and is bounded $(0,1)$. If actual imports are equal to the desired level, $\beta$ will equal unity; in contrast, a value of zero for the $\beta$ implies that equilibrium is never reached. The average or mean-time lag in adjustment can be calculated as $(1-\beta) / \beta$.

There are two particular variants of the general function (21) that are typically employed in trade studies. First, the partial-adjustment model which states that imports adjust to the difference between the demand for imports and actual imports in the previous period:

$$
\Delta I_{t}=\beta\left[I_{t}^{\mathrm{d}}-I_{t-1}\right] .
$$

By substituting for $I_{t}^{\mathrm{d}}$ one obtains a reduced form equation that differs from the equilibrium model of eq. (1) simply by the addition of a lagged imports term. A second variant of the Koyck model is one where demand and supply depend not on actual prices but rather on some notion of "expected" prices. If expectations are formed according to the adaptive-expectations model of Cagan (1956), one obtains an equation fairly similar to that yielded by the partial-adjustment model (22).

Estimates of import and export equations using some type of Koyck formulation have been made by Houthakker and Magee (1969), Magee (1970), and Goldstein and Khan (1976). These have shown that while adjustment is

\footnotetext{
${ }^{45}$ While we write the model in linear terms, it should be remembered that it could be defined in log-linear terms.
} 
not instantaneous, the lags are fairly short, with most of the effect occurring within four quarters or so. For example, Goldstein and Khan (1976) estimated the average lag in total import demand to be between two and four quarters for a group of seven industrial countries; while in another study [Goldstein and Khan (1978)], the same authors found that the average lag for total exports ranged between one and five quarters.

Provided due care is paid to the error structure in the estimation equations, geometric lag models are relatively straightforward to estimate and the results are easily interpreted. However, such specifications do have certain fundamental features which may not be fully acceptable. First, and by definition, these models assume that the largest effect of any change in the explanatory variables occurs in the initial period. In contrast, it could be argued that the true lag effect builds up gradually over time and declines after that. In other words, the appropriate lag pattern could be an inverted " $v$ " shape (or even a more complicated distribution) rather than the steadily declining lag pattern emerging from the Koyck-lag models. Some adjustment can be made to the general geometric distributed-lag model to allow for this, for example by permitting the first few lagged terms to be unrestricted, but in doing so one loses the theoretical rationales of the partial-adjustment and adaptive expectations models.

Another more serious problem with such models is that the lag in the response of the dependent variable is assumed to be the same irrespective of whether the change in imports is due to variation in prices or in the scale variable. It has been argued [for example by Magee (1975)] that there is no reason for the time response to be the same for all explanatory variables. Further, the lag that is estimated could be a combination of different lag patterns on the different explanatory variables. In this connection, the relatively short average lag that has been found in empirical studies using Koyck lags could primarily reflect a short real income lag that is not really valid for prices. A number of writers have argued that the delayed response of imports and exports due to recognition lags, decision lags, delivery lags, replacement lags, and production lags, ${ }^{46}$ is likely to be quite different depending on the explanatory variable that initiates the response. While there appears to be some agreement that the effect of real income or other scale variables is largest in the initial

${ }^{46}$ See Junz and Rhomberg (1973) for a discussion of these different types of lags. 
period and declines rapidly thereafter, there is much less of a consensus on the proper distributed-lag pattern for price changes. For this reason, it is generally not appropriate to impose a geometrically declining pattern a priori.

These problems with Koyck lags have led to the wide use of polynomial (Almon) lag models in estimating trade equations. Such formulations avoid the imposition of a uniform lag pattern on all the explanatory variables and permit less stringent restrictions on the shape of that lag distribution. The results from such experiments have been, to say the least, quite mixed. In general, the lag pattern associated with the scale variable has been quite similar to that yielded by the geometric lag model, but the responses of imports and exports to price changes have displayed a variety of lag patterns. Some writers [e.g. Heien (1968) and Samuelson (1973)] have found that the effect on imports of a relative price change decays steadily over time, with about 75 percent of the effect taking place in the first year and the remainder occurring in the following year. Others [e.g Buckler and Almon (1972), Clark (1977)] found a bell-shaped or inverted " $v$ " pattern for relative price changes. Applying the polynomial lag approach to aggregate import equations for twelve industrial countries, Goldstein and Khan (1976) discovered that the weights of the lag structure declined steadily in half the cases and either increased over time or took on the inverted bell shape in the other half. Interestingly, it was also found that the statistical significance of the relative price term was substantially lower than when a geometric lag structure was imposed.

Since polynomial lags allow for more flexibility than Koyck lags, they are perhaps better able to represent the reaction of the dependent variable to changes in the exogenous variables. However, the shape and form of the lag pattern is dependent on the degree of the polynomial, on whether endpoint constraints are imposed and if so in what way, and on the number of lags included. Naturally, the researcher cannot be expected to go through all possible permutations so that some degree of subjective prefiltering is invariably present in the lag forms selected. This makes it difficult to determine whether the reported lag structure is the result of a number of preliminary tests with the selection based on some criteria of goodness-of-fit, or whether it simply reflects the priors of the researcher. Furthermore, one often finds such lag structures, particularly those from models utilizing higher-order polynomials and a large number of lags, yielding signs on the coefficients for some of the lagged values that are clearly at variance with theoretical expectations [Minford 
(1978)]. While some rationalization of such results is typically provided, the arguments seem somewhat strained, since sign-switching of the coefficients of lagged values of the variables is extremely difficult to justify theoretically.

Some compromise between the geometric and polynomial lag models can be made by incorporating the main advantages of the two, although to our knowledge this has not yet been done in trade equations. Hall and Sutch (1967), for example, suggest that the initial part of the lag distribution be represented by a low-order polynomial and the latter part by a Koyck distribution. In the more general case, separate low-order polynomials could be applied to the scale and price variables, with a common geometric lag structure being applied after some point in time. This would yield a model that was more flexible than the Koyck-type model, yet at the same time avoid many of the problems associated with polynomial lags.

Another worrisome problem is that the estimated lag distributions in trade equations do not seem to be independent of the unit of observation. In other words, one can obtain strikingly different results for the same model depending on whether the unit observation of the data is monthly, quarterly, or annual. This is the familiar time-aggregation problem in econometrics. It is possible, for example, that the very long lags (up to six years) on relative prices reported by some researchers [Junz and Rhomberg (1973)] are simply a consequence of their use of pooled time-series cross-section data. Some relief from this timeaggregation problem could perhaps be obtained by considering the methods of estimation proposed by Sims (1971) and Wymer (1972). These methods, which essentially involve the discrete-time approximation of continuous-time models, yield estimates of lags that are apparently independent of the unit of observation. As far as we can ascertain, there has again as yet been no effort made in this direction.

Finally, it would seem that there is also considerable potential in the application of the techniques of time series analysis to trade relationships. This methodology, associated with the names of Box and Jenkins (1970), is very powerful in identifying and estimating general distributed-lag relationships. The techniques of ARIMA models and transfer functions are now widely available and thus can be readily applied. The principal advantage of such an approach is that it involves a minimum of arbitrariness in the choice of the lag distribution, as the data itself is allowed to determine the form and length of the lag process. 
In sum, the issue of timing is clearly a very crucial one in the estimation of trade relationships and has received a great deal of attention. Unfortunately, despite the energy expended on the topic, the issue is far from settled. We do not know the length of the lags involved and we are as yet unclear on how lag patterns ought to be modelled. Additional work in this area should still pay large positive marginal returns.

\subsection{Aggregation}

Since trade data are available on a disaggregated basis for most countries, it is relevant to ask two related questions. ${ }^{47}$ First, is it necessary to estimate disaggregated relationships and then combine them to obtain an aggregate estimate? Second, if the answer to the first question is in the affirmative, how should the aggregate values for the elasticities be derived from the estimates of the components?

The general guideline for disaggregation is quite simple. If the effect of the determining variables is exactly the same as between the aggregate and disaggregated groups, or if the relationship between the components and aggregate explanatory variables is a stable one, then one can be indifferent between the aggregate and disaggregated equations. ${ }^{48}$ If these basic preconditions are not satisfied, however, and they are unlikely to be satisfied in any realistic situation, disaggregation is always better, as the estimates obtained directly from the aggregate relationship are likely to be biased. This point was made persuasively by Orcutt (1950) for the case of price elasticities. In aggregate trade equations, goods with relatively low price elasticities can display the largest variation in prices and therefore exert a dominant effect on the estimated aggregate price elasticity, thereby biasing the estimate downwards. The same problem can in principle arise with respect to the scale variable, although here it is typically less serious.

\footnotetext{
${ }^{47}$ We deal here only with disaggregation over commodities, not over regions. The latter form of disaggregation can be viewed as another way of disaggregating by commodities, since certain regions trade in certain types of commodities. The other main rationale for regional disaggregation is to give expression to the assumed particular import demand behavior of developing countries; see, for example Rhomberg and Boissoneault (1965).

${ }^{48}$ See Madalla (1977).
} 
The relationship between the parameters obtained from estimates of disaggregated equations and those from the aggregate equation has been defined rigorously by Theil (1954). In the case of the aggregate import-demand equation, for example, the parameters of real income and prices will depend not only on the corresponding parameters of the disaggregated relationship but also on the parameters of the other included variables. In other words, the aggregate real income coefficient will be a weighted average of the disaggregated real income coefficients and the weighted average of the disaggregated price coefficients. Unless all the disaggregated coefficients are equal, estimation of the aggregate relationship, by ignoring this interaction, will result in specification bias.

Concern with the issue of aggregation bias has led to a number of empirical studies that use disaggregated import and export data. In most such studies, the disaggregation tends to be limited to a standard one-digit SITC classification, although some studies [Kreinin (1967), Khan (1975), and Stone (1979)] have been able to disaggregate more finely. Estimates of income and price elasticities for disaggregated commodity categories are examined in Section 4, and it is sufficient here to note that these elasticities differ across commodity groups, with price elasticities higher for manufactures than for non-manufactures. The activity or income elasticity of demand for manufactures also appears to be higher than those for the other groups, but perhaps less markedly.

If one accepts the view that disaggregation is usually warranted, how should one proceed to obtain aggregate elasticities from the disaggregated estimates? For a linear functional form of the equation, this is a relatively simple matter of taking the weighted average of the disaggregated estimates, with the weights being the shares of the components in the total. In the loglinear case, it has been demonstrated by Barker (1970) that one has to adjust the component elasticities by the variation in the component real incomes and prices relative to the variation in their respective aggregates. This ratio is generally referred to as the "distribution" factor. Thus, in the log-linear specification, a weighted average of the disaggregated import elasticities would equal the "true" elasticities only if the distribution factors were equal to one or if they were uncorrelated with the other terms. While it may be plausible to assume that these distribution factors for real income approximate unity, there is less reason to suppose that component price indices move exactly in proportion to the total price index. Both Magee (1975) and Khan (1975) found that import price elasticities calculated after adjusting for the distribution 
factor turned out to be significantly lower than those obtained utilizing the simple weighted average method.

Finally, it should be mentioned that while disaggregation may be preferable in principle, there has been some controversy on its merits in practice. If the disaggregated data are accurate and the component equations well specified, then disaggregation always results in more information. But Grunfeld and Griliches (1960) and Aigner and Goldfeld (1974) make the point that disaggregated data are generally subject to larger measurement errors than are aggregate data, and further that disaggregated functions are more likely to be misspecified than aggregate relationships. In such a case, it may be advisable to estimate the aggregate relationship. Essentially, the argument revolves around predictability, that is, whether predictions from a model using aggregate data are more accurate than those derived from disaggregated data. If the forecast errors from the disaggregated estimates cancel each other out, then disaggregation makes no difference. If such cancelling-out does not occur, the sum of forecast errors may be larger than those obtained from the aggregate relationship. Edwards and Orcutt (1969) show via simulation experiments that predictions from disaggregated data are much better than those from aggregated data, but this finding is challenged by Aigner and Goldfeld (1973) who show that this supposed superiority of disaggregated models cannot be generalized.

\subsection{Simultaneity}

As demonstrated by Orcutt (1950) and Prais (1962) among others, price elasticities in trade relationships can be seriously biased by simultaneity between quantities and prices. Thus, single-equation estimates of the price elasticities of demand and supply can be weighted averages of the "true" demand and supply elasticities and consequently can be biased downward. More formally, simultaneity implies correlation between the determining variables in an equation and the error term, which violates one of the conditions for the use of classical least squares analysis [Orcutt (1950), Harberger (1953), Kmenta (1971)]. The basic conditions under which one can proceed to estimate, say, a demand equation that would be free of such bias are either that the price elasticity of supply is infinite, or that the demand function is stable while the supply function shifts around. ${ }^{49}$

${ }^{49}$ For a formal analysis, see Madalla (1977) and Leamer (1981). 
When such assumptions cannot be made, there are basically two options. The first is to solve the model to obtain the reduced form, and then estimate that by ordinary least squares. Provided that the model is just identified, one can recover the price and income elasticities of demand and supply from the estimates of the reduced-form equations. However, one seldom has the luxury of having a just-identified model to work with, so that the latter step is often not possible. For example, Amano's (1974) study of export behavior of industrial countries eliminates the problems created by simultaneity, but the overidentified nature of the model prevents one from calculating either the demand or supply price elasticities. An alternative approach is to estimate the model using simultaneous equation methods. The earliest attempt at simultaneous estimation of trade equations is contained in the impressive study by Morgan and Corlett (1951), who estimated import demand and supply functions for various commodities by limited-information maximum-likelihood methods. While the results were quite poor, their approach was correct conceptually, and it has properly served as a model for later research. More recent studies, using techniques such as two-stage least squares or instrumental variables, include those by Rhomberg and Boissoneault (1965), Basevi (1973), Khan (1974), Artus (1975) and Gylfason (1978). It is not possible in many of these cases to derive the supply-price elasticity, but the procedure adopted does correct for simultaneity.

Explicit export-supply functions have been incorporated into export demand models by Magee (1970), Gylfason (1978) and Goldstein and Khan (1978)..$^{50}$ The last study formulates a two-equation model of exports and estimates the complete model simultaneously by full-information maximumlikelihood methods. All three studies introducing a supply function for exports found that this extension tended to raise the estimated price elasticity of demand (vis-a-vis the OLS estimates), a result that can be explained by the less-than-infinite supply-price elasticities found in these studies. Goldstein and Khan (1978), for example, report the latter as ranging from 1.1 to 6.6 for a group of seven industrial countries.

\footnotetext{
${ }^{50}$ Simultaneous estimation of import relationships has rarely been undertaken, although here one would probably be justified in assuming that, in all but a few large countries, the price of imports is unaffected by variations in an individual country's demand. For two such attempts to estimate import supply equations, see Magee (1970) and Gylfason (1978).
} 
Given the accumulated evidence, it would seem that simultaneity is not a problem that can be dealt with by assumption, particularly in relation to exports. Rather, the correct procedure is to formulate a complete model, test it, and then decide whether the price variable in the demand equation can be treated as exogenous. It needs to be recognized, however, that this procedure is laborious and there is always a risk of misspecification attached to the construction of complete models. Fortunately, there are certain statistical tests, such as the regression specification error test (RESET) due to Ramsey (1969), and the specification tests developed by Hausmann (1978), that can be applied in a single-equation context. These tests are quite powerful in detecting a nonzero mean disturbance that may be caused by omitted variables, incorrect functional form, or simultaneous-equation bias. Another option that has not been explored in the trade literature is to utilize the so-called "causality tests" due to Granger (1969) and Sims (1972), which enable one to test for feedback relations between variables. ${ }^{51}$

\subsection{Stability of Trade Relationships}

Whether a regression relationship varies or is stable over time is obviously important from both a predictive and an analytical point of view. Forecasts can be accurate only if the underlying equation on which they are based is unchanging. Similarly, determining the effects of changes of exogenous variables with any degree of confidence also requires that the parameters of the function be invariant over time. Changes in the basic relationship can be either gradual or sudden, and in either case the resulting parameters will be biased and inconsistent if allowance is not made for such shifts. There are in fact good reasons for expecting that trade relationships are subject to both types of changes. Gradual changes in the elasticities can come about as the pattern of trade changes during the process of economic development or as the result of changes in government trade policies. Sudden shocks such as changes in the exchange rate or exchange rate regime, or large oil price increases can also fundamentally alter the basic demand or supply relationships.

Yet another potential reason for instability of the parameters is the so called "quantum effect", originally suggested by Orcutt (1950). It is argued that the

\footnotetext{
${ }^{51}$ In other words, if there were no contemporaneous relationship between the variables in question one could be justified in estimating the model by classical least squares methods.
} 
price elasticity of demand for imports will be larger for large price changes than for small price changes. The rationalization for this quantum effect is that the price change must be large enough to overcome buyer inertia and the costs related to switching suppliers [see, for example, Liu (1954)]. Its chief implication is that estimates of elasticities based on a sample containing both large and small price changes will not be equally applicable in other situations where large or small price changes predominate.

The statistical procedures used to test for stability have typically involved the introduction of dummy variables to isolate the point at which the structural shift is suspected of taking place, and/or splitting the sample at this point and estimating the relevant functions for the two sub-periods. The latter approach was adopted by Kemp (1962b) for the case of Canadian imports. Estimating the import equation for sub-periods 1929-1939 and 1947-1955, Kemp (1962b) found that the income elasticity doubled in size. Magee (1972) used a similar approach on a bilateral model for U.S. imports and exports, and reported significant changes in both the price and income elasiticities as between the periods 1951-1960 and 1961-1969. Stability tests of a similar type have also been performed by Rhomberg and Boissoneault (1965) and Ahluwalia and Hernandez-Cata (1975) for U.S. exports and imports, respectively, and by Heien (1968) on import equations for a group of industrial countries.

More formal test to determine the constancy of the regression relationship over time have been conducted by Hooper (1978) and Stern et al. (1979). Hooper (1978) applied the standard approach of splitting the sample at the point where the shift is assumed to have occurred, and then proceeded to test whether the shift was statistically significant by using the $F$-test developed by Chow (I960). ${ }^{52}$ The results of that exercise indicated that the demand for U.S. nonagricultural exports had been relatively stable for the period under consideration, but that the U.S. nonoil import demand function had been unstable. Hooper (1978) then introduced additional variables into the import

\footnotetext{
52 An interesting search procedure was adopted by Hooper (1978) to determine the point of change in the relationship. It basically involves the estimation of export and import volume equations for the U.S. over a 24-quarter segment, then moving this segment along the overall sample (1957-77) year by year and repeating the estimation. Changes in the elasticities can be visually identified and the equations re-estimated for the sub-periods determined by this search procedure.
} 
demand function in a (partially successful) attempt to reduce the instability. This latter step, namely correcting in some way for the shift in the relationship, is rarely undertaken, so that the effort is to be commended. ${ }^{53}$

Identifying the point where a break in the relationship occurs is almost always a difficult task. Recently, however, new tests of stability have been developed, principally by Brown et al. (1975), that require no more information than is already contained in the data. Such tests have recently been applied to the case of the demand for aggregate U.S. imports and exports by Stern et al. (1979) over the period 1956-1976. The set of tests chosen, however, while powerful in detecting haphazard or nonsystematic shifts in the function, are not really suitable for the testing of gradual or secular changes. Brown et al. (1975) consider other tests more appropriate for the latter case, and it is advisable to employ the complete battery of tests instead of choosing a particular sub-set of such tests. ${ }^{54}$

The evidence on the quantum effect is somewhat mixed. The initial test of this hypothesis, conducted by Liu (1954), found the coefficient on a squared relative price-change variable in a equation for U.S. imports to be significantly different from zero and therefore concluded that the large/small price change distinction was a valid one, with large changes tending to raise the price elasticity. Goldstein and Khan (1976) tested the same quantum effect hypothesis for 12 industrial countries by allowing alternatively the import price elasticity and the speed of adjustment to vary with the size of the relative price change. They found no evidence that the price elasticity of demand for imports varied with the size of the price change, or that importers adjusted faster when faced with larger than "normal" price changes. These results, which held up when the tests were conducted at a lower level of disaggregation and with alternative lag structures, supported the more indirect tests reported by Magee (1975). In sum, notwithstanding Liu's (1954) results, there does not seem to be strong empirical support at this point for the quantum effect.

\footnotetext{
${ }^{53}$ Some other work has also been done on introducing the suspected cause of instability directly into the regression relationship. For example, Hooper and Kohlhagen (1978) introduce an exchange rate uncertainty variable into trade equations. A time trend to capture secular changes is also frequently employed.

${ }^{54}$ The reason for using several tests in combination is because departures from constancy of parameters may show up in different ways and the various tests may not be equally powerful in detecting the particular kind of departure encountered.
} 


\section{ESTIMATES OF PRICE AND INCOME ELASTICITIES AND RELATED POLICY ISSUES}

In this section we turn from questions of methodology to a presentation of the actual econometric estimates of price, income (activity), pass-through, and feedback elasticities, and to the policy issues associated with the size and time patterns of those elasticities. In order of appearance, we consider: (i) price and income elasticities of demand for imports and exports; (ii) the price elasticity of supply for exports, the pass-through of exchange rate changes onto localcurrency prices of imports and exports, and the elasticities of export price with respect to domestic costs and competitors' export prices; and (iii) the (feedback) elasticity of domestic prices with respect to changes in import prices and exchange rates. Following that, we offer some observations on the effectiveness of devaluation in improving a country's balance of payments.

To aid in the presentation of the empirical evidence, we have constructed summary tables of estimates for each of the elasicity parameters mentioned above. In selecting the entries for these tables, we have been guided by three considerations. First, because many interesting policy questions relate to intercountry differences in elasticities, we have given priority to multi-country studies since they usually use the same equation specification across countries. Second, to minimize duplication with earlier trade surveys [Magee (1975), Stern et al. (1976)], we have emphasized recent contributions (post 1973) and have seldom included estimates made prior to 1969. Third, we make no pretense of having compiled an exhaustive list of estimates but we have tried to cover the studies most frequently cited in the literature as well as those recent studies that, in our view, rest on the most solid methodological ground.

\subsection{Price and Income Elasticities of Demand for Imports and Exports}

As indicated earlier, most of empirical trade work has been confined to the estimation of demand functions for imports and exports that closely resemble eqs. (1) and (2) of the imperfect substitutes model. Tables 1-4 provide a condensed picture of the relative price and income elasticities that have emerged from these empirical studies.

Four broad conclusions stand out. First, the sum of the long-run (greater or equal to 2 years) price elasticities of demand for imports and exports invariably 
Table 1: Long-run Price Elasticities of Demand for Total Exports and Imports: Representative Estimates From Recent Studies

\begin{tabular}{|c|c|c|c|c|c|c|c|c|c|c|}
\hline \multirow[b]{2}{*}{ Country } & \multicolumn{10}{|c|}{ Total Exports } \\
\hline & $\begin{array}{l}\text { Houthakker- } \\
\text { Magee } \\
(1969)\end{array}$ & $\begin{array}{l}\text { Goldstein- } \\
\text { Khan } \\
(1978)\end{array}$ & $\begin{array}{l}\text { Hickman- } \\
\text { Lau } \\
(1973)\end{array}$ & $\begin{array}{l}\text { Beenstock- } \\
\text { Minford } \\
(1976)\end{array}$ & $\begin{array}{l}\text { Amano } \\
\text { et al. }^{\mathrm{a}} \\
(1981)\end{array}$ & $\begin{array}{l}\text { Basevi } \\
(1973)\end{array}$ & $\begin{array}{l}\text { Samuelson } \\
\text { (1973) }\end{array}$ & $\begin{array}{l}\text { Adams } \\
\text { et al. } \\
(1969)\end{array}$ & $\begin{array}{c}\text { Gylfason } \\
(1978)\end{array}$ & $\begin{array}{l}\text { Stern } \\
\text { et al. } \\
(1976)\end{array}$ \\
\hline Austria & n.a. & n.a. & -0.93 & n.a. & n.a. & n.a. & -1.21 & n.a. & $\ldots$ & -0.93 \\
\hline Belgium & $\ldots$ & -1.57 & -1.02 & -0.84 & n.a. & n.a. & -1.14 & $\ldots$ & $\ldots$ & -1.02 \\
\hline Canada & -0.59 & n.a. & -0.84 & -1.00 & -0.33 & -0.59 & -1.10 & -0.23 & $\ldots$ & -0.79 \\
\hline Denmark & -0.56 & n.a. & -1.28 & n.a. & n.a. & n.a. & -1.06 & n.a. & n.a. & -1.28 \\
\hline France & -2.27 & -1.33 & -1.09 & -1.59 & -0.34 & n.a. & -1.28 & -1.06 & $\ldots$ & -1.31 \\
\hline Germany & -1.25 & -0.83 & -1.04 & -1.90 & -0.29 & -1.68 & -1.12 & -0.65 & -0.38 & -1.11 \\
\hline Italy & -1.12 & -3.29 & -0.93 & -1.91 & -0.30 & -0.72 & -1.29 & -0.25 & -1.91 & -0.93 \\
\hline Japan & -0.80 & $\ldots$ & -0.50 & -3.00 & -0.81 & -2.38 & -1.04 & -0.71 & -2.13 & -1.25 \\
\hline Netherlands & $\ldots$ & -2.72 & -0.95 & -2.10 & n.a. & -2.39 & -1.07 & -0.59 & -0.88 & -0.95 \\
\hline Norway & $\ldots$ & n.a. & -0.80 & n.a. & n.a. & n.a. & -1.16 & n.a. & n.a. & -0.81 \\
\hline Sweden & -0.47 & n.a. & -1.99 & n.a. & n.a. & -1.92 & n.a. & n.a. & n.a. & -1.96 \\
\hline Switzerland & -0.58 & n.a. & -1.01 & n.a. & n.a. & n.a. & -1.51 & n.a. & n.a. & -1.01 \\
\hline United Kingdom & -1.24 & -1.32 & -1.27 & -1.47 & -0.08 & -0.71 & -1.28 & -0.48 & -0.32 & -0.48 \\
\hline United States & -1.51 & -2.32 & -1.38 & n.a. & -0.32 & -1.44 & -1.13 & -0.60 & -0.62 & -1.41 \\
\hline
\end{tabular}

\begin{tabular}{|c|c|c|c|c|c|c|c|c|c|c|}
\hline Japan & 0.00 & & 0.00 & 5.00 & 0.01 & 2.50 & $1.0 T$ & $0 . / 1$ & 2.15 & $1.2)$ \\
\hline Netherlands & $\ldots$ & -2.72 & -0.95 & -2.10 & n.a. & -2.39 & -1.07 & -0.59 & -0.88 & -0.95 \\
\hline Norway & $\ldots$ & n.a. & -0.80 & n.a. & n.a. & n.a. & -1.16 & n.a. & n.a. & -0.81 \\
\hline Sweden & -0.47 & n.a. & -1.99 & n.a. & n.a. & -1.92 & n.a. & n.a. & n.a. & -1.96 \\
\hline Switzerland & -0.58 & n.a. & -1.01 & n.a. & n.a. & n.a. & -1.51 & n.a. & n.a. & -1.01 \\
\hline United Kingdom & -1.24 & -1.32 & -1.27 & -1.47 & -0.08 & -0.71 & -1.28 & -0.48 & -0.32 & -0.48 \\
\hline United States & -1.51 & -2.32 & -1.38 & n.a. & -0.32 & -1.44 & -1.13 & -0.60 & -0.62 & -1.41 \\
\hline
\end{tabular}


Table 1: (Continued)

\begin{tabular}{|c|c|c|c|c|c|c|c|c|c|c|}
\hline \multirow[b]{2}{*}{ Country } & \multicolumn{10}{|c|}{ Total Imports } \\
\hline & $\begin{array}{c}\text { Houthakker- } \\
\text { Magee } \\
(1969)\end{array}$ & $\begin{array}{l}\text { Adams } \\
\text { et al. } \\
(1969)\end{array}$ & $\begin{array}{l}\text { Taplin } \\
\text { (1973) }\end{array}$ & $\begin{array}{l}\text { Goldstein- } \\
\text { Khan } \\
(1980)\end{array}$ & $\begin{array}{l}\text { Beenstock } \\
\text { Minford } \\
(1976)\end{array}$ & $\begin{array}{c}\text { Samuelson } \\
\text { (1973) }\end{array}$ & $\begin{array}{c}\text { Gylfason } \\
\text { (1978) }\end{array}$ & $\begin{array}{l}\text { Stern } \\
\text { et al. } \\
(1976)\end{array}$ & $\begin{array}{c}\text { Armington } \\
(1970)\end{array}$ & $\begin{array}{l}\text { Geraci and } \\
\text { Prewo } \\
(1980)\end{array}$ \\
\hline Austria & n.a. & n.a. & n.a. & -0.82 & n.a. & -1.42 & -1.21 & -1.32 & -1.37 & n.a. \\
\hline Belgium & -1.02 & -0.61 & -0.65 & -0.48 & -2.90 & $\ldots$ & -2.57 & -0.83 & -1.11 & n.a. \\
\hline Canada & -1.46 & -0.62 & -1.59 & -0.20 & -2.50 & -1.29 & $\ldots$ & -1.30 & -1.30 & n.a. \\
\hline Denmark & -1.66 & n.a. & -0.85 & -0.42 & n.a. & -0.23 & n.a. & -1.05 & -1.26 & n.a. \\
\hline France & $\ldots$ & -0.81 & -0.39 & n.a. & -1.31 & -0.79 & -0.46 & -1.80 & -1.53 & -0.33 \\
\hline Germany & -0.24 & -0.85 & -0.61 & -0.25 & -0.74 & -0.92 & -1.36 & -0.88 & -1.48 & -0.60 \\
\hline Italy & -0.13 & $\ldots$ & -1.03 & -0.45 & -0.88 & -1.01 & -0.32 & -1.03 & -1.42 & n.a. \\
\hline Japan & -0.72 & $\ldots$ & -0.81 & n.a. & -1.21 & $\ldots$ & $\ldots$ & -0.78 & -1.47 & -0.72 \\
\hline Netherlands & $\ldots$ & -0.24 & -0.02 & n.a. & $\ldots$ & $\cdots$ & -1.65 & -0.68 & -1.13 & n.a. \\
\hline Norway & $\ldots$ & n.a. & -1.20 & n.a. & n.a. & $\ldots$ & n.a. & -1.19 & -1.19 & n.a. \\
\hline Sweden & -0.79 & n.a. & -0.76 & -0.84 & n.a. & -0.80 & n.a. & -0.79 & -1.30 & n.a. \\
\hline Switzerland & -0.84 & n.a. & -1.10 & n.a. & n.a. & $\ldots$ & n.a. & -1.22 & -1.35 & n.a. \\
\hline United Kingdom & -0.21 & $\ldots$ & -0.22 & $\ldots$ & $\ldots$ & $\ldots$ & $\ldots$ & -0.65 & -1.38 & -0.79 \\
\hline United States & -1.03 & -1.16 & -1.05 & -1.12 & -1.04 & $\cdots$ & -1.12 & -1.66 & -1.73 & -1.23 \\
\hline
\end{tabular}

${ }^{\text {a } U n w e i g h t e d ~ a v e r a g e ~ o f ~(c o r r e c t l y-s i g n e d) ~ e s t i m a t e s ~ i n ~ T a b l e ~ 1-2 . ~}$

... indicates zero or wrong-signed coefficient on relative prices. 
Table 2: Short-run versus Long-run Price Elasticities of Demand for Imports and Exports: Representative Estimates

\begin{tabular}{|c|c|c|c|c|c|c|c|c|}
\hline & (1) & (2) & (3) & (4) & (5) & (6) & (7) & (8) \\
\hline Investigator & $\begin{array}{c}\text { Short-run } \\
\text { (0-6 Months) } \\
\text { Price } \\
\text { Elasticity }\end{array}$ & $\begin{array}{l}\text { Long-run } \\
\text { (>2 Years) } \\
\text { Price } \\
\text { Elasticity }\end{array}$ & $\begin{array}{l}\text { Ratio of } \\
\text { Long-run to } \\
\text { Short-run } \\
\text { Elasticity }\end{array}$ & $\begin{array}{l}\text { Time Period } \\
\text { (in Years) for } \\
50 \% \text { of Final } \\
\text { Price Effect }\end{array}$ & $\begin{array}{l}\text { Total } \\
\text { Length (in } \\
\text { Years) of Lag } \\
\text { Distribution }\end{array}$ & $\begin{array}{c}\text { Type of } \\
\text { Distributed } \\
\text { Lag }\end{array}$ & $\begin{array}{l}\text { Level of } \\
\text { Aggregation }\end{array}$ & $\begin{array}{l}\text { Type of } \\
\text { Equation }\end{array}$ \\
\hline \multirow[t]{2}{*}{ (1) Hooper (1976) } & -0.42 & -0.54 & 1.3 & $<0.25$ & 2 & Polynomial & U.S. nonfuel imports & $\begin{array}{l}\text { Standard import } \\
\text { demand }\end{array}$ \\
\hline & -0.17 & -0.79 & 4.6 & 1.00 & 2 & Polynomial & $\begin{array}{l}\text { U.S. nonagricultural } \\
\text { exports }\end{array}$ & $\begin{array}{l}\text { Standard export } \\
\text { demand }\end{array}$ \\
\hline \multirow[t]{2}{*}{$\begin{array}{l}\text { (2) Lawrence } \\
\text { (1978) }\end{array}$} & -0.14 & -1.52 & 10.8 & $1-1.5$ & 2 & Polynomial & $\begin{array}{l}\text { U.S. imports of } \\
\text { manufactures }\end{array}$ & $\begin{array}{l}\text { Standard import } \\
\text { demand }\end{array}$ \\
\hline & -0.17 & -1.85 & 10.8 & $1-1.5$ & 2 & Polynomial & $\begin{array}{l}\text { U.S. exports of } \\
\text { manufactures }\end{array}$ & $\begin{array}{l}\text { Standard export } \\
\text { demand }\end{array}$ \\
\hline \multirow[t]{2}{*}{$\begin{array}{l}\text { (3) Deppler and } \\
\text { Ripley (1978) }\end{array}$} & -0.50 & -0.97 & 1.9 & $\approx 1.0$ & 3.5 & Discrete & $\begin{array}{l}\text { Imports of manufactures } \\
\text { (unweighted average, } 14 \\
\text { industrial countries) }\end{array}$ & $\begin{array}{l}\text { Standard import } \\
\text { demand }\end{array}$ \\
\hline & -0.80 & -1.40 & 1.7 & $\approx 1.0$ & 3.5 & Discrete & $\begin{array}{l}\text { Exports of manufactures } \\
\text { (unweighted average, } 14 \\
\text { industrial countries) }\end{array}$ & $\begin{array}{l}\text { Standard export } \\
\text { demand }\end{array}$ \\
\hline \multirow[t]{2}{*}{$\begin{array}{l}\text { (4) Beenstock and } \\
\text { Minford (1976) }\end{array}$} & -0.50 & -1.18 & 2.4 & $0.5-1.0$ & up to 5 & Polynomial & $\begin{array}{l}\text { Total imports unweighted } \\
\text { average, } 9 \text { industrial } \\
\text { countries }\end{array}$ & $\begin{array}{l}\text { Standard import } \\
\text { demand }\end{array}$ \\
\hline & -0.70 & -1.73 & 2.5 & $0.5-1.0$ & up to 5 & Polynomial & $\begin{array}{l}\text { Total exports, unweighted } \\
\text { average, } 8 \text { industrial } \\
\text { countries }\end{array}$ & $\begin{array}{l}\text { Standard export } \\
\text { demand }\end{array}$ \\
\hline
\end{tabular}


Table 2: (Continued)

\begin{tabular}{|c|c|c|c|c|c|c|c|c|}
\hline & (1) & (2) & (3) & (4) & (5) & (6) & (7) & (8) \\
\hline Investigator & $\begin{array}{c}\text { Short-run } \\
\text { (0-6 Months) } \\
\text { Price } \\
\text { Elasticity }\end{array}$ & $\begin{array}{l}\text { Long-run } \\
\text { (>2 Years) } \\
\text { Price } \\
\text { Elasticity }\end{array}$ & $\begin{array}{l}\text { Ratio of } \\
\text { Long-run to } \\
\text { Short-run } \\
\text { Elasticity }\end{array}$ & $\begin{array}{l}\text { Time period } \\
\text { (in Years) for } \\
50 \% \text { of Final } \\
\text { Price Effect }\end{array}$ & $\begin{array}{l}\text { Total } \\
\text { Length (in } \\
\text { Years) of Lag } \\
\text { Distribution }\end{array}$ & $\begin{array}{c}\text { Type of } \\
\text { Distributed } \\
\text { Lag }\end{array}$ & $\begin{array}{c}\text { Level of } \\
\text { Aggregation }\end{array}$ & $\begin{array}{l}\text { Type of } \\
\text { Equation }\end{array}$ \\
\hline $\begin{array}{l}\text { (5) Goldstein and } \\
\text { Khan (1978) }\end{array}$ & -0.76 & -1.35 & 1.8 & $<0.25$ & $\infty$ & Koyck & $\begin{array}{l}\text { Total exports, unweighted } \\
\text { average, } 8 \text { industrial } \\
\text { countries }\end{array}$ & $\begin{array}{l}\text { Standard export } \\
\text { demand }\end{array}$ \\
\hline (6) Taplin (1973) & -0.32 & -1.33 & 4.2 & $>5.0$ & $\infty$ & Koyck & $\begin{array}{l}\text { Total exports, pooled, } \\
\text { cross-section for } \\
\text { industrial countries }\end{array}$ & $\begin{array}{l}\text { Elasticity of } \\
\text { substitution } \\
\text { framework }\end{array}$ \\
\hline (7) Heien (1968) & -0.77 & -0.93 & 1.2 & $<1$ & 3 & Variety & $\begin{array}{l}\text { Total imports, unweighted } \\
\text { average, } 11 \text { industrial } \\
\text { countries }\end{array}$ & $\begin{array}{l}\text { Standard import } \\
\text { demand }\end{array}$ \\
\hline $\begin{array}{l}\text { (8) Junz and } \\
\text { Rhomberg } \\
\text { (1973) }\end{array}$ & -1.52 & -3.88 & 2.5 & 2 & 5 & Discrete & $\begin{array}{l}\text { Manufactured exports } \\
\text { pooled, cross-section } 13 \\
\text { industrial countries }\end{array}$ & $\begin{array}{l}\text { Elasticity of } \\
\text { substitution } \\
\text { framework }\end{array}$ \\
\hline $\begin{array}{l}\text { (9) Artus and Sosa } \\
\text { (1978) }\end{array}$ & -0.07 & -0.77 & 11.0 & n.a. & 3 & Discrete & $\begin{array}{l}13 \text { industrial countries } \\
\text { Exports of nonelectrical } \\
\text { machinery ( } 3 \text { industrial } \\
\text { countries) }\end{array}$ & $\begin{array}{c}\text { Elasticity of } \\
\text { substitution } \\
\text { framework }\end{array}$ \\
\hline $\begin{array}{l}\text { (10) Hickman and } \\
\text { Lau (1973) }\end{array}$ & -0.63 & -0.95 & 1.5 & - & - & & $\begin{array}{l}\text { Total exports of } 25 \\
\text { industrial countries }\end{array}$ & $\begin{array}{c}\text { Elasticity of } \\
\text { substitution } \\
\text { framework }\end{array}$ \\
\hline
\end{tabular}


Table 3: Long-run Activity Elasticities for Total Exports and Total Imports

\begin{tabular}{|c|c|c|c|c|c|c|c|}
\hline \multirow[b]{3}{*}{ Country } & \multicolumn{6}{|c|}{ Total Exports } & \\
\hline & (1) & (2) & (3) & $(4)$ & (5) & (6) & \\
\hline & $\begin{array}{c}\text { Houthakker- } \\
\text { Magee } \\
(1969)\end{array}$ & $\begin{array}{l}\text { Basevi } \\
(1973)\end{array}$ & $\begin{array}{l}\text { Goldstein- } \\
\text { Khan } \\
(1978)\end{array}$ & $\begin{array}{l}\text { Deppler- } \\
\text { Ripley } \\
(1978)^{\mathrm{a}, \mathrm{b}}\end{array}$ & $\begin{array}{l}\text { Balassa } \\
(1979)^{\mathrm{C}}\end{array}$ & $\begin{array}{l}\text { Wilson- } \\
\text { Takacs } \\
(1979)\end{array}$ & \\
\hline Austria & n.a. & n.a. & n.a. & 1.08 & 2.04 & n.a. & \\
\hline Belgium & 1.87 & 1.29 & 1.68 & 1.03 & 1.98 & n.a. & \\
\hline Canada & 1.41 & 1.15 & n.a. & 0.69 & 1.89 & 1.97 & \\
\hline Denmark & 1.69 & n.a. & n.a. & 1.08 & 1.82 & n.a. & \\
\hline France & 1.53 & n.a. & 1.69 & 0.70 & 2.04 & 2.14 & \\
\hline Germany & 0.91 & 1.33 & 1.80 & 1.11 & 2.27 & 1.59 & \\
\hline Italy & 2.68 & 1.18 & 1.96 & 1.12 & 2.07 & n.a. & \\
\hline Japan & 3.55 & 1.62 & 4.22 & 1.45 & 2.00 & n.a. & \\
\hline Netherlands & 1.88 & 0.85 & 1.91 & 0.65 & 1.91 & n.a. & \\
\hline Norway & 1.59 & n.a. & n.a. & 0.75 & 1.82 & n.a. & \\
\hline Sweden & 1.75 & 1.22 & n.a. & 1.14 & 1.93 & n.a. & \\
\hline Switzerland & 1.47 & n.a. & n.a. & 0.82 & n.a. & n.a. & \\
\hline United Kingdom & 1.00 & 0.61 & 0.92 & 0.90 & 2.20 & 1.75 & \\
\hline \multirow[t]{4}{*}{ United States } & 0.99 & 0.92 & 1.01 & 1.32 & 2.02 & 2.15 & \\
\hline & \multicolumn{7}{|c|}{ Total Imports } \\
\hline & (1) & (2) & (3) & (4) & (5) & (6) & (7) \\
\hline & $\begin{array}{c}\text { Houthakker- } \\
\text { Magee } \\
(1969)\end{array}$ & $\begin{array}{l}\text { Taplin } \\
(1973)\end{array}$ & $\begin{array}{l}\text { Goldstein- } \\
\text { Khan } \\
(1976)\end{array}$ & $\begin{array}{c}\text { Samuelson } \\
\text { (1973) }\end{array}$ & $\begin{array}{l}\text { Adams } \\
\text { et al. } \\
(1969)\end{array}$ & $\begin{array}{l}\text { Geraci- } \\
\text { Prewo } \\
(1980)\end{array}$ & $\begin{array}{l}\text { Wilson- } \\
\text { Takacs } \\
(1979)\end{array}$ \\
\hline Austria & n.a. & 1.04 & n.a. & 1.08 & n.a. & n.a. & n.a. \\
\hline Belgium & 1.94 & 1.27 & 1.75 & 1.38 & 1.21 & n.a. & n.a. \\
\hline Canada & 1.20 & 1.18 & n.a. & 0.95 & 0.90 & n.a. & 1.87 \\
\hline Denmark & 1.31 & 1.08 & 0.84 & 1.38 & n.a. & n.a. & n.a. \\
\hline France & 1.66 & 1.30 & 1.28 & 1.45 & 1.32 & 1.57 & 1.07 \\
\hline Germany & 1.85 & 1.35 & 1.52 & 1.17 & 1.34 & 1.42 & 1.46 \\
\hline Italy & 2.19 & 1.26 & 1.83 & 1.86 & 1.35 & n.a. & n.a. \\
\hline Japan & 1.23 & 1.12 & 1.30 & 1.26 & 0.93 & 0.77 & 1.69 \\
\hline Netherlands & 1.89 & 1.27 & 2.04 & 1.56 & 1.35 & n.a. & n.a. \\
\hline Norway & 1.40 & 0.90 & 1.01 & 1.63 & n.a. & n.a. & n.a. \\
\hline Sweden & 1.42 & 1.02 & 1.33 & 1.13 & n.a. & n.a. & n.a. \\
\hline Switzerland & 2.05 & 1.25 & n.a. & 1.46 & 1.07 & n.a. & n.a. \\
\hline United Kingdom & 1.45 & 1.24 & 1.78 & 1.46 & 1.07 & 2.24 & 2.57 \\
\hline United States & 1.68 & 1.81 & 1.84 & 1.89 & 0.76 & 1.53 & 4.03 \\
\hline
\end{tabular}

${ }^{a}$ Refers to manufactured exports only.

${ }^{b}$ Refers to cyclical changes in real income.

${ }^{\mathrm{c}}$ Refers to trend (permanent) real income. 
Table 4: Long-run Price and Activity Elasticities for Disaggregated Import Categories: Some Representative Estimates

\begin{tabular}{|c|c|c|c|c|c|c|c|c|c|}
\hline $\begin{array}{l}\text { Commodity } \\
\text { categories }\end{array}$ & $\begin{array}{c}\text { Deppler-Ripley } \\
(1978)^{\mathrm{a}}\end{array}$ & $\begin{array}{l}\text { Taplin } \\
(1973)^{\mathrm{b}}\end{array}$ & $\begin{array}{c}\text { Basevi } \\
(1973)^{\mathrm{C}}\end{array}$ & $\begin{array}{l}\text { Clark } \\
(1977)^{\mathrm{C}}\end{array}$ & $\begin{array}{l}\text { Ball-Marwah } \\
\qquad(1962)^{\mathrm{d}}\end{array}$ & $\begin{array}{c}\text { Houthakker- } \\
\text { Magee } \\
(1969)^{\mathrm{d}}\end{array}$ & $\begin{array}{l}\text { Barker } \\
(1976)^{\mathrm{e}}\end{array}$ & $\begin{array}{l}\text { Stern } e t \text { al. } \\
(1976)^{f}\end{array}$ & $\begin{array}{l}\text { Theil and } \\
\text { Clements } \\
(1978)^{g}\end{array}$ \\
\hline & \multicolumn{9}{|c|}{ Price elasticities } \\
\hline $\begin{array}{l}\text { Foods and beverages } \\
\qquad(\text { SITC } 0+1)\end{array}$ & -0.34 & -0.57 & -0.55 & -1.14 & -0.47 & -0.18 to -1.28 & -0.13 to -0.18 & -0.78 & -0.58 \\
\hline $\begin{array}{l}\text { Raw materials } \\
\quad(\text { SITC } 2+4)\end{array}$ & - & -0.63 & -0.13 & -1.25 & -0.83 & $-1.18^{\mathrm{h}}$ & $-0.44^{\mathrm{h}}$ & -0.50 & -0.95 \\
\hline Fuels (SITC3) & - & -0.63 & -0.04 & - & n.a. & & & -0.96 & n.a. \\
\hline \multirow[t]{2}{*}{$\begin{array}{l}\text { Manufactures and misc. } \\
\text { goods (SITC5-9) }\end{array}$} & -0.97 & -1.23 & -0.71 & -4.72 & -1.98 & -1.8 to -4.0 & -1.37 & -1.34 & -1.16 to -1.4 \\
\hline & \multicolumn{9}{|c|}{ Activity elasticities } \\
\hline $\begin{array}{l}\text { Foods and beverages } \\
\qquad(\text { SITC } 0+1)\end{array}$ & 2.83 & 0.84 & 1.08 & 0.38 & 0.96 & 0.30 to 1.28 & 1.12 to 1.16 & n.a. & 0.14 \\
\hline $\begin{array}{l}\text { Raw materials } \\
\quad(\text { SITC } 2+4)\end{array}$ & 0.32 & 0.75 & 0.83 & 0.96 & 1.15 & $0.61^{\mathrm{h}}$ & $1.91^{\mathrm{h}}$ & n.a. & 0.25 \\
\hline Fuels (SITC3) & 1.22 & 0.96 & 1.40 & - & n.a. & - & & n.a. & n.a. \\
\hline $\begin{array}{l}\text { Manufactures and misc. } \\
\text { goods (SITC5-9) }\end{array}$ & 1.27 & 1.44 & 1.46 & 2.60 & 2.07 & 1.11 & 1.99 & n.a. & 0.28 to 0.32 \\
\hline
\end{tabular}

${ }^{a}$ Unweighted average, 14 industrial countries.

${ }^{b}$ Unweighted average, 25 industrial or semi-industrial countries.

${ }^{\mathrm{c}}$ Unweighted average, 10 industrial countries.

${ }^{\mathrm{d}}$ United States.

${ }^{\mathrm{e}}$ United Kingdom.

${ }^{\mathrm{f}}$ Median estimate, all industrial countries.

gPooled, cross-section for 13 industrial countries.

${ }^{\mathrm{h}}$ Raw materials plus fuels. 
exceeds one for industrial countries (Table 1). ${ }^{55}$ Thus, if the Marshall-Lerner condition (together with infinite supply elasticities) is regarded as the dividing line between elasticity optimists and pessimists, we read Table 1 as firmly in the camp of the elasticity optimists. On the import side, Harberger's (1957) judgment of 25 years ago that the price elasticity of import demand for a typical country "... lies in or above the range of -0.5 to -1.0 " still seems on the mark; his corresponding consensus export price elasticity of "... near or above -2 " appears somewhat on the high side (a range of -1.25 to -2.50 would be our consensus estimate) but would be consistent with those studies that either estimate export price elasticities of demand in a simultaneous framework [e.g. Goldstein and Khan (1978)] or employ long lag distributions on the export price variable [e.g. Beenstock and Minford (1976)]. In short, the estimates in Table 1 suggest that over a period of two to three years, relative prices do play a powerful role in the demand for total imports and exports. ${ }^{56}$ As such, the potential contribution of expenditureswitching policy instruments (the exchange rate, tariffs and subsidies) to trade balance adjustment is a strong one.

The second conclusion, brought out forcefully in Table 2, is that shortrun (0-6 months) price elasticities of demand for imports and exports are considerably smaller than the long-run elasticities. The considerable variation across studies in the estimated shape and length of the lag distribution on relative prices makes it hazardous to offer specific estimates of the relationship

\footnotetext{
${ }^{55}$ The only borderline case in Table 1 is the United Kingdom; here however, the results of other econometric studies [Barker (1976), Winters (1976)] strongly suggest that when U.K. imports and exports are disaggregated by commodity class, the aggregate price elasticities of demand increase significantly, suggesting that aggregation bias is perhaps a more serious problem in trade equations for the United Kingdom than in those for other countries.

The low estimated export price elasticities obtained in the recent study by Amano et al. (1981) for the seven major industrial countries are not so easy to dismiss. Until further work is done, we will not be able to tell whether these reflect some unusual features of their sample period (1971-1977), or specification and estimation differences, or a true secular decline in the price elasticities themselves.

${ }^{56}$ The range of estimated price elasticities in Table 1 is quite wide, and Kohli (1982) has shown how large differences in price elasticities can result from seemingly small differences in the definition of the scale and domestic price variables (e.g. real national income versus real national product) even when derived form the same structural model; further these differences in elasticities across alternative definitions of the right-hand-side variables increase with the size of the country's foreign trade sector.
} 
between short-run and long-run elasticities. ${ }^{57}$ Nevertheless, the evidence in Table 2 would not be inconsistent with the judgment that long-run price elasticities are roughly twice as high as short-run ones, and that about 50 percent of the final relative price adjustment takes place within a one-year period.

This marked difference between short-run and long-run price elasticities of demand carries at least two policy implications. ${ }^{58}$ One is that the trade balance response to devaluation can follow a pattern described by the " $J$ curve". The value of the trade balance can worsen in the short run in response to devaluation because of low short-run price elasticities of demand and the tendency for import prices to rise more rapidly in local currency terms than export prices. Over time, the price elasticities of demand grow larger and export prices catchup with import prices, with the result that the initial deterioration in the trade balance is halted and then reversed. Nevertheless, the preverse initial response of the trade balance can frequently last for say four to five quarters and it can amount to as much as 10 percent of the local-currency value of imports [Spitaeller (1980)].

The second and most significant implication of low short-run price elasticities is that short-run changes in countries' trade balances will then be dominated by real income movements at home and abroad. A comparison of the short-run price elasticities in Table 2 with the income elasticities of demand in Table 3, reveals that for periods up to one year in length, the sum of income elasticities for imports and exports is anywhere from two to four times larger than the respective sum of price elasticities. Consistent with this conclusion, most detailed analyses of short to medium-term changes in current account positions among major industrial countries [e.g. Wallich (1978), Truman (1978)] point to differential real income movements across countries as the key explanatory factor.

\footnotetext{
${ }^{57}$ As illustrated in Table 2, three of the troubling aspects of the estimates of time lags on relative prices are: (i) the tendency for the estimated long-run price elasticities to vary positively with the assumed length of the lag distribution; (ii) the tendency for studies based on pooled timeseries and cross-section data [e.g. Junz and Rhomberg (1973)] to yield much longer lags than those based on time-series data for single countries; and (iii) the tendency for the polynomial lags to yield longer average lags than either the Koyck or discrete unconstrained distributed lag formulations.

${ }^{58}$ This subsection draws heavily on arguments presented in Goldstein (1980).
} 
Our third broad conclusion, based on the estimates shown in Table 3, is that income elasticities of demand for a representative industrial country fall in the range of 1 to 2 on both the import and export sides. This carries two implications. The first is that in the absence of secular increases in the relative price of imports, one should expect the shares of imports and exports in GNP (in real terms) to be rising over time. Evidence collected by Salant (1977, Tables 2 and 3) shows that this is just what has been happening, at least for industrial countries as a group since the late 1940s. The second implication is more controversial and relates to differences across countries in the relationship between income elasticities of demand for exports versus imports. If the income elasticity of demand for a country's imports is significantly larger than that for its exports, then the country confronts an unpalatable choice: either grow at the same rate as its trading partners and accept a secular deterioration in its balance, or to opt for external balance and accept a slower growth rate than its trading partners. ${ }^{59}$

This issue of unequal income elasticities first attracted attention in the empirical literature in the paper by Houthakker and Magee (1969), where the authors found that the income elasticity for Japan's exports was substantially higher than that for its imports, whereas the United Kingdom and the United States were in the opposite category - a finding that seemed to be consistent with the strong trade account performance of Japan and the weak performances of the United Kingdom and the United States during much of the 1960s. As shown in Table 3, subsequent multi-country econometric studies have on balance replicated this inter-country pattern of income elasticities. ${ }^{60}$ Still, serious questions have been raised about both the existence and interpretation of the Houthakker-Magee income-elasticity effect. On the first count, Hooper (1978) has advanced the argument that the observed

\footnotetext{
${ }^{59}$ If income elasticities for imports and exports are the same, then conventional trade models of course yields the implication that a country which grows faster than its trading partners will suffer a deterioration in its trade balance. Indeed, such nonsynchronization of growth rates is typically at the root of most explanations for large switches in current account positions; e.g. see Truman (1978), Lawrence (1978), Wallich (1978).

${ }^{60}$ An exception is the recent study by Balassa (1979). This study however uses a constantmarket-shares approach to export modelling and this renders the "apparent" income elasticities derived from it noncomparable in a strict sense with income elasticities from traditional export demand equations.
} 
high estimated income-elasticity of demand for U.S. imports reflects the positive correlation between U.S. income growth and a relevant omitted variable, namely, supply capacity in the exporting countries, particularly the newly-industrialized developing countries. Under normal circumstances, such increases in supply capacity would be reflected in export prices and hence in U.S. import prices. In this case however, so Hooper (1978) argues, these exports contained many new products with zero or unduly low weights in the standard price indices; hence, this supply effect was not reflected in recorded movements in U.S. import prices. When a supply proxy for foreign production is included in the U.S. import demand function along with the normal arguments, the estimated income elasticity of demand drops from above two to somewhere between 1.3 and 1.7. This still leaves the income elasticity for U.S. nonoil imports above that for U.S. nonagricultural exports (1.2) but the difference is no longer substantial. Similar views that the high estimated income elasticity for Japanese exports may really be picking up the influence of some collinear omitted variable have often been put forward but less success has been achieved in identifying just what that omitted variable could be.

A second challenge to the Houthakker-Magee thesis is that it neither differentiates between the trade balance effects of secular versus cyclical income movements nor does it account for the (positive) effect of secular income movements on export supply. Bazdarich (1979), for example, has noted that cyclical increases in U.S. GNP have generally been associated with deterioration in the U.S. trade balance and dollar depreciation whereas increases in potential or trend GNP have had the opposite effect. Perhaps more interesting, Geraci and Prewo (1980) found that while the long-run income elasticity of demand for U.S. imports was high (1.5), it was low relative to the long-run export supply elasticity with respect to trend real income (2.5). Similarly, the trend-income demand elasticity for imports was low relative to the trend-income supply elasticity for exports for Japan, whereas the two elasticities were quite close together for France, Germany, and the United Kingdom. Although Geraci and Prewo (1980) interpret their findings as consistent with persistent trade surpluses by the United States (1958-1974) and Japan, their results could still be compatible with the Houthakker-Magee thesis if it was export demand rather than export supply that was the constraint on actual exports during the sample period. 
A final criticism of the Houthakker-Magee hypothesis, and indeed of all income-based trade models, is that the analysis is too partial-equilibrium in nature. One branch of the criticism, as represented in recent papers by McKinnon (1978), Artus (1979), and Sachs (1981), reminds us of Alexander's (1952) fundamental insight that the current account surplus must be equal to the difference between income and expenditure or, to what is the same thing, to the difference between savings and investment. ${ }^{61}$ Application of this "absorption view" to the observed current account imbalances of the 1970s yields the conclusion that the observed imbalances reflected inter-country differences in the incentives to savings and investment [Artus (1979)] and inter-country differences in shifts in investment induced in turn by intercountry differences in permanent income [Sachs (1981)]. Note that the two approaches (income and absorption) need not be incompatible if, as suggested in Section 2, conventional import and export demand equations use permanent or life-cycle income as the scale variable rather than current income.

Our fourth broad conclusion is based on the estimates shown in Table 4. There are significant differences in both price and income elasticities of demand across commodity groups. More particularly, the price elasticity of demand for manufactures is significantly larger than that for nonmanufactures. ${ }^{62} \mathrm{Within}$ nonmanufactures, price elasticities for raw materials and fuels appear to be larger than those for food and beverages, but the differences do not seem large. In the case of the activity elasticities, the comparisons are clouded by the use of different activity variables across commodity groups but, on balance, we again see a higher elasticity for manufactures (especially if estimates of the activity elasticity for fuels do not reflect recent conservation efforts). The chief implication of these inter-commodity differences in income and price elasticities is that differences in the commodity structure of trade can lead both to differences across countries in price and income elasticities for their total

\footnotetext{
${ }^{61}$ Another branch of criticism comes from the monetary approach [Frenkel and Johnson (1976)] which predicts that countries with high growth rates of real income will run balance-of-payments surpluses because of the positive effect of higher real income on the demand for real money balances.

${ }^{62}$ We have restricted Table 4 to imports because most export demand equations for nonmanufactures omit any relative price term, implying that the price elasticity for these goods is either zero or infinite.
} 
imports and exports and to differences in elasticities as between the exports and imports of a single country.

But differences in the commodity composition of trade are not the only explanation for the observed inter-country differences in price elasticities of demand. In fact, two other explanations have already been alluded to in Section 2, namely differences in the share of imports in total domestic demand and supply, as in eq. (17) of the perfect substitutes model, and differences in the share of imports in total domestic demand, as derived from eq. (20) of the Armington model. Yet another explanation, which is highlighted in an interesting recent study by Goldsbrough (1981), is that price elasticities are much smaller for intra-firm trade (trade among affiliates of the same firm) than for conventional trade, and that the share of intra-firm trade in total trade differs across countries. ${ }^{63}$ Given the resources that have been devoted to estimating price elasticities and the implications of inter-country differences in these elasticities for, say, the required change in exchange rates needed to remove existing trade imbalances, a strong case can be made for doing more research on competing explanations for inter-country differences in price elasticities. $^{64}$

\footnotetext{
${ }^{63}$ Still a fourth explanation is Vernon's (1966) "product cycle" which implies that the size of a country's price elasticities will depend on its stage in the product cycle, i.e. on whether it is exporting new and technologically-intensive manufactured goods (early stage) or exporting or importing these goods once their production has become standardized (later stage). Price elasticities are expected to be low in the early stage of the product cycle and high in the later stages. The same theory also implies differences in price elasticities as between a single country's exports and imports [Magee (1975)].

${ }^{64}$ As an initial modest step in this direction, we performed some simple rank correlations between the ordinal rankings of countries by size of price elasticity, as indicated by the studies in Table 1, and the ordinal rankings that emerge alternatively from differences in the commodity structure of imports and from differences in the share of imports in total domestic demand and supply. For the commodity structure model, we assigned each country the same import price elasticity of demand for each of the four broad commodity groups listed in Table 4. In this way, cross-country differences in the price elasticity of demand for total imports reflect solely crosscountry differences in the structure (value shares) of imports across commodities. Similarly, by using eq. (17) of the perfect substitutes model, and by assigning each country the same price elasticities of demand $\left(1_{1}\right)$ and supply $\left(n_{1}\right)$ for importables, we were able to generate crosscountry differences in the price elasticity of demand for total imports $\left(\varepsilon_{I}^{\mathrm{d}}\right)$ that reflect solely cross-country differences in the shares of imports in domestic demand $\left(I_{i} / D_{i}\right)$ and in domestic supply $\left(I_{i} / S_{i}\right)$. The commodity structure model yielded considerably higher correlation with the econometric results than did the perfect substitutes (or the Armington) model.
} 


\subsection{Supply Elasticities, Import and Export Pass-throughs, and Export Price Determination}

Despite over thirty years of econometric work on trade equations, it does not take a very large table to present a reasonably comprehensive list of existing estimates of the price elasticity of supply for exports. ${ }^{65}$ Table 5 presents those estimates, most of which come from export supply functions similar to those presented in the imperfect substitutes model of Section 2 [eq. (4)].

Although the supply-elasticity estimates show somewhat more variation across studies than did the demand-price elasticities, the following conclusions emerge from Table 5. First, excluding the United States, the supply-price elasticity for the total exports of a representative industrial country appears to be in the range of one to four. The supply elasticity for U.S. exports is probably considerably higher than that, perhaps even reaching ten to twelve. Second, there is a tendency in the empirical results for the estimated export supply elasticity to vary positively with the size of the exporting country (as measured say by its real GNP) and negatively with the ratio of export openness. Gylfason (1978), for example, reports a rank correlation of 0.66 between his estimates of export supply elasticities and the real GNP of the sample countries, and one of -0.43 between the supply elasticities and the ratios of exports to GNP. ${ }^{66}$ The relatively high degrees of export openness of Germany and the United Kingdom may explain why their estimated supply-price elasticities are smaller than might be expected on the basis of their size alone. A third conclusion is that supply-price elasticities for disaggregated exports are higher than those for total exports. This is consistent with a priori reasoning, as resources for expanding production of total exports can come only from the import-competing or nontradable sector, whereas resources for expanding exports of one industry can come from other export industries as well. The fourth but more tentative conclusion is that time lags in the adjustment of export supply to price changes are longer than those on the demand side [Geraci and Prewo (1980)]. This

\footnotetext{
${ }^{65}$ As regards estimates of supply-price elasticities for imports, even a table is unnecessary. In the recent literature, we know only of Magee's (1970) estimate for U.S. imports of finished manufactures and Gylfason's (1978) estimates of imports supply for some industrial countries. ${ }^{66}$ In a similar vein, Magee (1970) suggests that a back-of-the-envelope method for estimating a country's supply-price elasticity for total exports is to multiply the ratio of GNP to exports by two. He derives this formula from the observation that his estimated supply-price elasticity for U.S. exports is roughly twice the ratio of U.S. GNP to exports.
} 
Table 5: Estimates of Long-run Supply-price Elasticity for Exports

\begin{tabular}{|c|c|c|c|}
\hline Investigator & $\begin{array}{l}\text { Supply-price } \\
\text { Elasticity }\end{array}$ & $\begin{array}{c}\text { Level of } \\
\text { Aggregation }\end{array}$ & Country \\
\hline (1) Magee (1970) & 11.5 & Total exports & United States \\
\hline \multirow{7}{*}{$\begin{array}{l}\text { (2) Goldstein and Khan } \\
\text { (1978) }\end{array}$} & 6.6 & Total exports & United States \\
\hline & 4.6 & Total exports & Germany \\
\hline & 2.5 & Total exports & Netherlands \\
\hline & 1.9 & Total exports & France \\
\hline & 1.4 & Total exports & United Kingdom \\
\hline & 1.2 & Total exports & Belgium \\
\hline & 1.1 & Total exports & Italy \\
\hline \multirow[t]{2}{*}{ (3) Dunlevy (1979) } & 2.1 & Exports of manufactures & United States \\
\hline & 0.7 & Total exports & United Kingdom \\
\hline \multirow[t]{2}{*}{ (4) Basevi (1973) } & 3.8 & $\begin{array}{l}\text { Exports of chemicals and } \\
\text { fertilizers to U.S.A. }\end{array}$ & Canada \\
\hline & 4.9 & $\begin{array}{l}\text { Exports of minerals and } \\
\text { metals to world (less } \\
\text { U.S.A.) }\end{array}$ & Canada \\
\hline \multirow[t]{3}{*}{$\begin{array}{l}\text { (5) Artus and Sosa } \\
\text { (1978) }\end{array}$} & 4.6 & $\begin{array}{l}\text { Exports of nonelectrical } \\
\text { machinery }\end{array}$ & Germany \\
\hline & 4.2 & $\begin{array}{l}\text { Exports of nonelectrical } \\
\text { machinery }\end{array}$ & United Kingdom \\
\hline & 3.1 & $\begin{array}{l}\text { Exports of nonelectrical } \\
\text { machinery }\end{array}$ & United States \\
\hline \multirow[t]{6}{*}{ (6) Gylfason (1978) } & 2.4 & Total exports & United States \\
\hline & 1.7 & Total exports & Japan \\
\hline & 1.4 & Total exports & Netherlands \\
\hline & 0.8 & Total exports & Germany \\
\hline & 0.8 & Total exports & United Kingdom \\
\hline & 0.5 & Total exports & Italy \\
\hline \multirow{4}{*}{$\begin{array}{l}\text { (7) Geraci and Prewo } \\
(1980)\end{array}$} & 12.2 & Total exports & United States \\
\hline & 6.7 & Total exports & Japan \\
\hline & 4.6 & Total exports & Germany \\
\hline & 1.4 & Total exports & United Kingdom \\
\hline
\end{tabular}

may reflect the larger start-up costs associated with export production, different skill requirements in export production than in the rest of the economy, or the greater degree of uncertainty associated with selling abroad rather than domestically. 
Because the evidence on export supply elasticities is so meagre, the policy implications that one can draw from this evidence are likewise thin. The observation that export supply elasticities differ significantly across countries does suggest, however, that export subsidies and other incentives to exporting will not yield the same export supply responses across countries. In other words, even if comprehensive codes could be legislated and enforced that would equalize export subsidies across countries, some countries (most likely the larger, less open ones) would still get more export-supply response than others.

Another implication, and one that relies only on the conclusion that export supply elasticities are less than infinite, is that export prices in domestic currency will move to offset some (or even all) of the effect of a change in the exchange rate on the foreign-currency price of exports. In other words, the "pass-through" of exchange rate changes into export price changes (in foreign currency terms) will be less than complete. ${ }^{67}$ The consequence for the trade balance effect of an exchange rate change, however, depends on the size of the price elasticity of demand for exports. ${ }^{68}$ If the demand elasticity is greater than or equal to unity, a lower supply elasticity reduces the effect of an exchange rate change on the value of the trade balance; alternatively, when demand is inelastic, a lower supply elasticity enlarges the effects of an exchange rate change. The often-cited conclusion that devaluation can still be effective when the sum of the demand elasticities is less than unity so long as supply elasticities are less than infinite [e.g. Gylfason (1978)], is just an implication of this general result. The reasoning for this result is no different than in domestic applications of price theory: an inelastic supply curve produces a larger price

\footnotetext{
${ }^{67}$ Branson (1972, p. 21$)$ shows that the percentage change in export prices in foreign currency terms $(\mathrm{d} P X / P X)$ associated with a percentage change in the exchange rate $(\mathrm{d} e / e)$, call it $k$, can be expressed as:

$$
k=(\mathrm{d} P X / P X) /(\mathrm{d} e / e)=\left(l-\left(\varepsilon_{x}^{\mathrm{d}} / \varepsilon_{x}^{\mathrm{s}}\right)\right)^{-1},
$$

where $\varepsilon_{x}^{\mathrm{d}}$ and $\varepsilon_{x}^{s}$ are the demand-price and supply-elasticities for exports, respectively. Note that since $-\infty \leq \varepsilon_{x}^{\mathrm{d}} \leq 0$ and $\infty \leq \varepsilon_{x}^{s} \leq 0$, an infinite supply elasticity for exports implies full "pass-through" ( $k=1)$ of exchange rate changes into export price changes, whereas a zero export supply elasticity implies no pass through $(k=0)$; by analogy, note also that when the demand elasticity is infinite, $k=0$, whereas $k=1$ when the demand elasticity is zero.

${ }^{68}$ The case for imports is symmetrical to that for exports.
} 
Table 6: Estimates of Import and Export Price Changes (in Domestic Currency Terms) in Response to a 10 Percent Devaluation

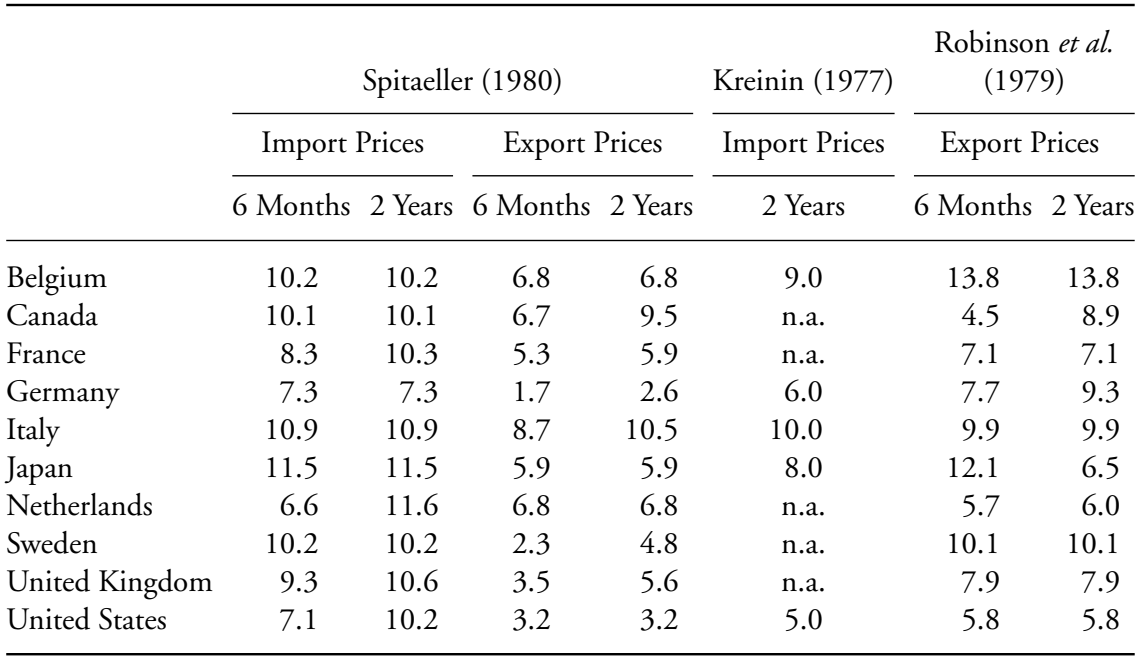

increase for a given rightward shift of the demand curve than an elastic one, and the impact of that price increase on the value of sales depends on whether demand is elastic or not. Since the weight of the evidence in Table 1 is that demand price elasticities are greater than unity in the long run, we interpret the lower-than-infinite export supply elasticities as a factor that will diminish the trade balance effects of exchange rate changes.

An alternative to inferring the size of export and import-price passthroughs from estimates of demand and supply price elasticities is to estimate these pass-throughs directly by regressing import or export prices on exchange rates. One strong advantage of this latter approach is that if high-frequency data (monthly, quarterly) are used, the results can tell us something useful about the timing of the response of import and export prices to exchange rate changes.

Table 6 presents some representative estimates of import and export-price responses (pass-throughs) to a hypothetical 10 percent devaluation in the country's currency. Three features of the evidence in Table 6 merit explicit mention. First, there is a marked tendency for import prices to rise more quickly (in domestic currency) than export prices in response to devaluation; the contrast is particularly evident in the short run (six months) but still 
holds, albeit to a lesser degree, in the medium run (two years). As suggested earlier, this type of price behavior, in combination with low short-run price elasticities of demand, are what accounts for the " $J$-curve" response of the trade balance to a devaluation. Second, time lags in the import-price pass-through are short; typically the effect is complete in six months, except perhaps for the largest industrial countries which have significant buying power on the international market. Thus, Spitaeller (1980) finds that import prices rise by the full extent of the devaluation in all countries except Germany, whereas Kreinin (1977) finds significant departure from full passthrough only for the United States and Germany. Recalling our preceding discussion of supply elasticities, the finding of full import price pass-through is consistent with the proposition that import supply elasticities are large relative to both import demand elasticities and export-supply elasticities, particularly over the short term. Full import price pass-through also implies that countries cannot count on much slippage between exchange rate changes and import price changes as a moderating factor in the domestic price feedback effects of exchange rate changes. A third feature of the evidence in Table 6 is the larger degree of export price pass-through in the smaller more-open industrial countries than in the larger less-open ones. For example, Robinson et al.'s (1979) estimates suggest that within two years of a devaluation, the domestic currency price of total exports will rise so as to offset nearly 100 percent of the devaluation for small open economies (e.g. Sweden, Austria, Belgium), 70-90 percent for mediumsized economies (e.g. France, Germany, Italy, the United Kingdom), and roughly 60 percent for large, relatively-closed economies (Japan, the United States). Spitaeller's (1980) export pass-through estimates are lower but convey a similar cross-country pattern. ${ }^{69}$ The clear message is that the larger less-open countries will, ceteris paribus, be able to hold the initial competitive exportprice advantage obtained by devaluation longer than the smaller more-open industrial countries [Goldstein (1980)].

Table 7 provides some complementary evidence on export price determination but this time drawing on empirical studies where imperfect competition

\footnotetext{
${ }^{69}$ Other empirical work on export price pass-throughs also shows that the size of the passthrough falls with the share of manufactures in total exports, implying that those countries with high shares of manufactures in total exports will be able to retain the competitive price advantage from devaluation longer than those with relatively high shares of primary commodities in total exports.
} 
Table 7: Elasticity of Export Prices of Manufactures with Respect to Domestic Prices or Wage Costs and Competitors' Export Prices

\begin{tabular}{|c|c|c|c|c|c|c|}
\hline \multirow[b]{2}{*}{ Country } & \multicolumn{2}{|c|}{$\begin{array}{c}\text { Deppler-Ripley } \\
\text { (1978) }\end{array}$} & \multicolumn{2}{|c|}{ Artus (1974) } & \multicolumn{2}{|c|}{$\begin{array}{l}\text { Samuelson } \\
\text { (1973) }\end{array}$} \\
\hline & $\begin{array}{l}\text { Unit labor } \\
\text { Costs }\end{array}$ & $\begin{array}{c}\text { Competitors' } \\
\text { Prices }\end{array}$ & $\begin{array}{l}\text { Wage } \\
\text { Rates }\end{array}$ & $\begin{array}{c}\text { Competitors' } \\
\text { Prices }\end{array}$ & $\begin{array}{l}\text { Domestic } \\
\text { Prices }\end{array}$ & $\begin{array}{c}\text { Competitors' } \\
\text { Prices }\end{array}$ \\
\hline Austria & $\cdots$ & 1.02 & n.a. & n.a. & $\cdots$ & 0.21 \\
\hline Belgium & 0.51 & 0.44 & n.a. & n.a. & $\cdots$ & 0.78 \\
\hline Canada & 0.49 & 0.46 & n.a. & n.a. & 0.67 & $\cdots$ \\
\hline Denmark & 0.26 & 0.66 & n.a. & n.a. & 0.36 & 0.46 \\
\hline France & 0.56 & 0.40 & 0.71 & 0.41 & 0.42 & 0.59 \\
\hline Germany & 0.57 & 0.40 & 0.58 & 0.36 & 0.38 & $\ldots$ \\
\hline Italy & 0.19 & 0.44 & & & $\ldots$ & 0.80 \\
\hline Japan & 0.58 & 0.58 & 0.42 & 0.54 & $\cdots$ & 0.60 \\
\hline Netherlands & $\ldots$ & 0.24 & n.a. & n.a. & 0.15 & 0.56 \\
\hline Norway & $\cdots$ & 1.31 & n.a. & n.a. & $\cdots$ & 0.96 \\
\hline Sweden & $\ldots$ & 0.99 & n.a. & n.a. & 0.39 & 0.83 \\
\hline Switzerland & $\cdots$ & 0.32 & n.a. & n.a. & 1.05 & $\cdots$ \\
\hline United Kingdom & 0.42 & 0.51 & 0.62 & 0.11 & 0.82 & 0.27 \\
\hline United States & 1.53 & $\cdots$ & 0.85 & 0.09 & 0.99 & 0.19 \\
\hline
\end{tabular}

is the maintained hypothesis. In these studies, the "mark-up" export price equation [e.g. eq. $\left(4^{\prime}\right)$ ] replaces the export supply model [e.g. eq. (4)]. The two determinants of export price that are accorded major importance in Table 7 are competitors' export prices and domestic factor costs. The interesting thing about the estimated elasticities of export price with respect to these two determinants is not so much their absolute size as their relative size across different groups of countries. ${ }^{70}$ Here, we find a consistent pattern. The smaller more-open countries apparently base their export prices on competitors' export prices; conversely, the larger less-open countries apparently use domestic factor costs or prices as the prime mover of export prices. Theoretical justifications for this finding are presented in Deppler and Ripley (1978) and Beenstock

\footnotetext{
${ }^{70}$ The reader may note that the elasticity of export price with respect to competitors' export prices often differs from the elasticity with respect to the exchange rate, even though in theory they should be equal. Spitaeller (1980) provides a case for unequal elasticities in terms of the shares of different currencies used in invoicing exports and imports. More general implications of alternative mixes of invoice currencies are analyzed in Magee (1973) and Magee and Rao (1980).
} 
and Minford (1976), among others. The basic idea is that the relative weight given to competitors' export prices $\left(P X_{C}\right)$ in export price determination will vary positively with the price elasticity of demand for the country's exports and with the slope of the marginal cost curve for producing exportables. Small countries, so the argument goes, with their small shares of world trade and limited domestic factor supplies, face both nearly perfect competition for their exports and sharply rising marginal costs in export production; hence, export prices follow competitors' prices with an elasticity close to one. At the other end of the spectrum are the large countries with their higher trade shares (and assumed higher degree of monopoly power) and larger production bases that together mean lower demand price elasticities for their exports and flatter marginal cost curves; this translates in turn into export price formation that is dominated by domestic factor cost behavior. Other factors that can influence the relative contributions of competitors' prices and domestic costs are the degree of specialization of exports (more specialization reduces the weight of $P X_{\mathrm{c}}$ ), the degree of capacity utilization (higher utilization increases the weight of $P X_{\mathrm{c}}$ ), and the share of exportables in total production (a higher export share increases the weight of $P X_{\mathrm{c}}$ ).

In sum, the imperfect-competition export price models imply that countries can be classified as either "price makers" (price-transmitters) or "price takers" (price-receivers) on the basis of the structural characteristics that govern the demand and supply elasticities for their exports. While these characteristics need not be fully captured by size and degree of openness, the empirical results do identify the larger less-open industrial countries as the ones with the most latitude in export pricing and hence, also with the greatest potential for holding on longest to the export price advantage conferred by devaluation. These models also highlight the importance of the domestic cost and price feedback effects of exchange rate changes for relative traded goods prices. It is to this latter topic that we now turn.

\subsection{Domestic Price Feedback Effects of Import Price Changes}

Table 8 presents some representative estimates of the effect of import price changes on the three most widely-used aggregate domestic price indices (i.e. the consumer price index, the wholesale price index, and the GDP deflator). The tale told by Table 8 and the associated empirical literature can be summarized as 
Table 8: Estimates of the Elasticity of Domestic Prices with Respect to Changes in Import Prices

\begin{tabular}{|c|c|c|c|c|}
\hline & \multicolumn{2}{|c|}{ Consumer Prices } & \multirow{2}{*}{$\begin{array}{l}\text { Wholesale Prices } \\
\text { Beenstock and } \\
\text { Minford (1976) }\end{array}$} & \multirow{2}{*}{$\begin{array}{c}\text { GDP Deflator } \\
\text { Artus and } \\
\text { McGuirk (1981) }\end{array}$} \\
\hline & $\begin{array}{c}\text { Dornbusch and } \\
\text { Krugman (1976) }\end{array}$ & $\begin{array}{l}\text { Spitaeller } \\
(1980)\end{array}$ & & \\
\hline Canada & 0.20 & 0.24 & 0.28 & 0.17 \\
\hline France & 0.16 & 0.32 & 0.28 & 0.23 \\
\hline Germany & 0.03 & 0.08 & 0.23 & 0.22 \\
\hline Italy & 0.28 & 0.36 & - & 0.16 \\
\hline Japan & 0.24 & n.a. & 0.20 & 0.14 \\
\hline United Kingdom & 0.19 & 0.20 & - & 0.27 \\
\hline United States & 0.14 & 0.16 & 0.05 & 0.14 \\
\hline
\end{tabular}

follows. ${ }^{71}$ First, import price changes do have a sizeable effect on the domestic price level in industrial countries. A consensus estimate would be that a 10 percent change in import prices leads eventually to a change in domestic prices of anywhere from 1.5 to 4.0 percent for a "representative" industrial country. ${ }^{72}$ In this regard, Bruno (1978) in a pooled cross-section time-series regression for 16 OECD countries over the 1972-1976 period, found that each 10 percent change in import prices was associated with a 1.8 percent change in consumer prices. Second, time lags in the pass-through of import price changes onto domestic price changes are longer than those associated with the pass-through of exchange rate changes into import price changes, but most studies find that roughly half of the final domestic price effect takes place within one year. Where long lags are apparent, they are usually explainable in terms of institutional arrangements that limit the frequency with which wages can be renegotiated to take account of unexpected developments in the cost of living, exchange rate-induced or otherwise. Third, there are large differences

\footnotetext{
${ }^{71}$ In addition to the studies listed in Table 8, estimates of the effect of import price changes on domestic prices can be found in Goldstein (1977), and Hooper and Lowry (1979).

${ }^{72}$ From time to time the argument has been made that positive changes in import prices have a greater proportionate effect on domestic prices than negative ones, thereby leading to a progressive "ratcheting-up" of domestic prices in the face of exchange rate fluctuations. The arguments and empirical evidence for such a "ratchet effect" have been examined by Goldstein (1977), who finds little support for it. A somewhat more sympathetic verdict is offered by Kenen and Pack (1979).
} 
across countries in the effect of import price changes on domestic prices, with the United States clearly being at the low end of the spectrum among the seven major industrial countries, and with the United Kingdom, France, and Italy at the upper end. Furthermore, if some of the smaller more-open industrial countries (e.g. Belgium, the Netherlands) were included in Table 8, it is possible that they would show even larger domestic price feedbacks. The very low estimated feedback elasticity for Germany's consumer prices is surprising in view of Germany's size and openness; in this respect, the feedback estimates for Germany's wholesale prices and its GDP deflator are probably more reliable.

If the domestic price effect of import price changes is significant and varies across countries, we can next ask what determines the size of that effect? Theory and empirical work suggest four principal factors: (i) the substitutability between imported and domestic goods in consumption and production; (ii) the share of imports in final expenditure or total output; (iii) the elasticity of factor prices, particularly money wages, with respect to actual (or expected) domestic price changes; and (iv) the elasticity of domestic prices with respect to changes in factor prices (again, principally money wages). The higher are each of these parameters, the greater will be the elasticity of domestic prices with respect to import price changes. ${ }^{73}$

If imports were perfect substitutes for domestic goods, then the domestic price equation would be a simple one; the only explanatory variable would be import prices and it would carry an estimated coefficient of unity [Isard (1977b)]. As indicated earlier, however, in our discussion of the "law of one price", the empirical literature has rejected the perfect substitutes hypothesis. This means that import price increases and decreases can still generate "sympathetic" and "disciplinary" effects respectively on domestic prices of similar goods, but that these effects are likely to be much smaller than unity [Kravis and Lipsey (1978)]. ${ }^{74}$

Where imports represent inputs to production, standard production theory predicts that the elasticity of domestic prices with respect to import prices should be approximated by the (value) share of imports in total output, at

\footnotetext{
${ }^{73}$ See Goldstein (1974), Ball et al. (1977) and Bruno (1978).

74 de Melo and Robinson (1981) show how the degrees of demand and supply substitution also affect the domestic price effects of changes in tariff and (export) subsidy rates.
} 
least in the case of a Cobb-Douglas production function; [Ball et al. (1977)]. ${ }^{75}$ Thus, ceteris paribus, the more "import-open" the economy, the greater should be the domestic price effects of import price changes. Further, since countries differ much more with regard to the sizes of their import shares [Salant (1977)] than to either labor's share in total output or the response of money wages to domestic inflation, it is likely that this first factor is the dominant source of the inter-country variation in the elasticity of domestic prices with respect to import prices that we observe in the empirical studies. ${ }^{76}$

If there was some money illusion in the 1950s and 1960s, there does not seem to be any left in the 1970s and 1980s, to judge from the unitary coefficient on expected inflation rates now commonly found in aggregate wage equations [Santomero and Seater (1978)]. But this does not mean that the money wage response to domestic price changes is the same in all countries. In some countries money wages are formally indexed to the cost of living on practically a one-for-one basis; in other countries indexation is used but with a price index that specifically omits changes in the terms of trade; in other countries recourse has sometimes been made to incomes policies that guarantee labor an increased real wage; and in still others, indexation itself is prohibited. ${ }^{77}$ All of this, plus differences across countries in the basic bargaining power of unions vis-à-vis employers, leads to differences in what Sachs (1980) calls the degree of "real wage resistance" among countries. Where indexation is widespread and where downward real wage resistance is strong, the domestic price effects of import price changes will likewise be strong.

What then are the policy implications of this feedback effect of import price changes on domestic prices? In our view, there are two major ones. The first is that the feedback effects can sharply diminish the real exchange rate changes that result from nominal exchange rate changes, and thereby

\footnotetext{
${ }^{75}$ Note that substitutability still counts here, but it is the substitution in production between imports and other factor inputs (labor, capital) that matters, not that between similar final goods in expenditure.

${ }^{76}$ Bruno (1978) dissents on this point. He finds small inter-country/differences in the effect of $P I$ on $P$ within a pooled time-series cross-section framework, and explains this by arguing that countries are more similar in the share of tradables in production and consumption than import or export data suggest.

77 A good review of inter-country differences in indexation practices can be found in Braun (1976).
} 
sharply reduce the expenditure-switching effects of such exchange rate changes even in the face of both reasonably high demand and supply elasticities for imports and exports and of supporting macroeconomic policies that keep a firm handle on the level of demand. Artus and McGuirk (1981) use the Fund's multilateral exchange rate model to contrast the trade balance effects of a 10 percent devaluation under low and high domestic price feedbacks. For the low feedback simulation, the elasticities of wages and the cost of capital with respect to the cost-of-living index are 0.5 and 0.3 , respectively; in the high feedback simulation, these two elasticities jump to 0.85 and 0.70 , respectively. Holding everything else constant, the trade balance effects with high domestic price feedback turn out to be only 60 percent as large as those with low feedback. In short, high domestic price feedback makes exchange rate changes less effective. ${ }^{78,79}$

The second implication of domestic price feedbacks arises out of their timing. Because the domestic price effects of exchange rate changes typically appear much before the resource allocation effects (due to low short-run price elasticities of demand and supply), there is a sense in which the "costs" of devaluation come before the "benefits" ${ }^{80}$ This timing problem can act as a serious obstacle to devaluation itself.

\subsection{Overview of the Effectiveness of Exchange Rate Changes}

Since so much of the empirical trade literature over the past thirty years has focused on estimating price elasticities to determine whether devaluation "works" (i.e. improves the current account), it could seem appropriate to conclude this section with some broad generalizations on the effectiveness of exchange rate changes.

\footnotetext{
${ }^{78}$ Indeed, some observers [e.g. Lewis (1976)] have gone farther. They argue that with floating rates the domestic price feedback effects of exchange rate changes induce further depreciation of the exchange rate, thereby drawing high inflation countries into a "vicious circle" of high inflation and exchange rate depreciation, and low-inflation countries into a "virtuous circle" of price stability and exchange rate appreciation. This argument however neglects the role of excess money balances in driving both the inflation rate and the exchange rate, as well as other factors that help to put a check on the circle; see Bilson (1979), and Goldstein (1980).

${ }^{79}$ We speak here only of the expenditure-switching role of exchange rate changes. Even if domestic prices to rise by the full extent of the devaluation, the current account may improve as economic agents reduce expenditure to restore their desired level of real money balances.

${ }^{80}$ Of course, the same argument implies that benefits precede the costs in the case of revaluation.
} 
(1) Relative prices matter. There is nothing in the empirical evidence on price elasticities themselves to indicate that their magnitude would be a barrier to successful devaluation over a time period of two to three years. Recent efforts to isolate the medium-term expenditure-switching effects of exchange rate changes [e.g. Artus and McGuirk (1981)] suggest that a 10 percent devaluation, along with low domestic price feedback, would improve the trade balance of a representative industrial country by somewhere between 4 and 10 percent of the initial value of trade; the corresponding figure for high domestic feedback would be roughly half that large. In this sense, we interpret the existing empirical evidence as endorsing Harberger's (1957) conclusion that "... the price mechanism works powerfully and pervasively in international trade".

(2) The short run is not, however, the same as the medium or long run. For time periods up to six months or perhaps even a year, the low trade volume response combined with the more rapid rise in local currency import prices than in export prices can quite commonly produce a deterioration in the trade balance of the depreciating country. In a similar vein, the domestic price feedback effects of exchange rate changes will appear before the resource allocation effects. In small, relatively open, highly-indexed economies, a 10 percent devaluation might well yield a 5 percent rise in the cost of living within a year.

(3) Relative prices are not the only things that matter. Whatever the price elasticities of demand and supply for imports, exports, tradables, and nontradables, it is worth remembering the lesson of the absorption approach that an improvement in the current account requires a reduction in expenditure relative to income; likewise, the monetary approach reminds us that there is a capital account as well as a current account, and that an exchange rate-induced excess demand for real money balances, if permitted to arise, can be satisfied from either channel. Both of these lessons are relevant for interpreting case histories of exchange rate changes [Laffer (1977), Miles (1979)]. In our view, before/after trade balance comparisons that indicate that devaluation does not work are typically instead examples of: lack of supporting expenditurereducing policies (usually the offsetting of the positive effect of devaluation on the demand for real money balances by expansions in the money supply), of longer-term incentive patterns that favor expenditure over saving, of faster adjustment speeds in asset than in goods markets that cause devaluation to 
work via the capital rather than the current account, or of accompanying trade policies that swamp the goods market effect of devaluation. In such circumstances, it is easy for the association between nominal exchange rate changes and current account imbalances to look weak even in the long run.

(4) Countries are different. While we read the empirical evidence as supportive of the effectiveness of exchange rate changes, we do not read it as supportive of equal effectiveness across countries. Differences in the commodity composition of trade, in degrees of import and export openness, in the degree of capacity utilization, in the degree of real wage resistance, and in the efficacy of monetary and fiscal policies all count. Although it is difficult to generalize on the basis of just one or two characteristics, it is our impression that the larger, less-open industrial countries face smaller domestic price feedbacks and can hold on to more of the initial competitive price advantage conferred by exchange rate changes than the smaller, more-open countries. Consistent with this, world trade models typically show a higher trade balance elasticity with respect to the exchange rate for the former group than for the latter. ${ }^{81}$ These inter-country differences in the effectiveness of devaluation may also explain why countries often hold different views on the optimal degree of exchange rate flexibility.

\section{CONCLUDING OBSERVATIONS}

In some respects, empirical work on the time-series behavior of foreign trade flows has changed little over the past thirty years. The major thrust of this literature is still by and large single-equation studies that regress import or export volumes on the level of real economic activity at home or abroad and on relative traded goods' prices, with attention closely focused on the estimated income and price elasticities of demand. Despite the dramatic improvement in estimation techniques and capabilities, our review of the empirical evidence also did not uncover any indication that there have been dramatic changes in the sizes of these elasticities themselves over this period. While harder to document, we likewise suspect that the uses to which these elasticities are put are still pretty much the same, with forecasts of trade balances under

${ }^{81}$ See Artus and McGuirk (1981). 
alternative growth and inflation paths and simulations of the expenditureswitching effects of exchange rate changes leading the way. Finally, most of the major methodological pitfalls in the specification and estimation of trade models that currently preoccupy researchers had already been identified by the early 1950s.

But all of this should not convey the impression that we have learned little of late about income and price effects in foreign trade. As illustrated in the previous three sections, noteworthy advances have been registered in understanding, inter alia, the determinants of export supply and export prices, the role of nonprice rationing in both import demand and export supply, the domestic price feedback effects of exchange rate changes, differences between short-run and long-run price elasticities of demand and between secular and cyclical income elasticities, the theoretical framework appropriate for computing all the own and cross-price elasticities of demand associated with a set of multilateral relative price changes for traded goods, the practical consequences for estimated price and income elasticities of measurement error in the price data, improper aggregation across commodity groups, ignoring the simultaneity between trade volumes and trade prices, and of the possibility of instability in the basic relationships.

At the same time, it is also apparent from our survey of the literature that existing empirical work is subject to some serious criticisms and that significant gaps remain to be filled by future research. To be more specific, there is in our view still a tendency for empirical trade work to be isolated from what is happening in macroeconomic theory. Two prominent examples of this isolation are the neglect of "permanent" or "life-cycle" income constructs in aggregate import and export demand functions and the absence of "expected" prices from export supply functions. Given the maintained hypothesis that imports and exports are (imperfect) substitutes for domestic goods, it does not make sense to have one theory of consumption or of aggregate supply for domestically-produced goods and another quite different one for imports and exports. Also, application of these concepts to trade models would help to remedy another shortcoming of this literature, namely the tendency for intertemporal considerations to be almost exclusively backward-looking rather than forward-looking.

A second broad area in which existing trade models come up short is in the integration of the real and financial sectors, i.e. in the interaction of goods and 
asset markets. Such integration would not be necessary if partial-equilibrium trade models were used only to answer partial-equilibrium questions. These trade models, however, are frequently employed to answer general-equilibrium questions that impinge on asset markets as well as goods markets, such as what would be the current account repercussions of exchange rate changes or of across-the-board tariff reductions. Such questions can be restricted by assumption to expenditure-switching effects in the goods market (i.e. one can assume that the authorities act to hold the overall level of final domestic demand constant), but it would be useful to know more about the implications for other macro variables, even under a constant-expenditure policy. This need not mean that trade models, if they are to be useful, should be appendages of large-scale economy-wide macro models; but it does suggest that we need to know more about to how the scale and relative price variables in trade equations are influenced by traditional macro policy instruments (monetary and fiscal policy) and how slower speeds of adjustment in goods than in asset markets will affect the short- and medium-run response of trade flows to internal and external price and income shocks.

Closer to the traditional pastures of trade modelling, we still see a significant pay-off to additional econometric work on time lags in export and import volume equations. As discussed in Sections 3 and 4, the existing literature has not yet produced anything approaching a consensus on the mean lag in the response of trade volumes to relative price changes despite, many studies on just that subject. More concretely, we have suggested ways in which the better qualities of geometric and polynomial distributed lags might be combined for this purpose; similarly, it would be worthwhile applying recent advances in time-series estimation to get a better handle on these lags. But better econometric methods alone are not likely to be sufficient. We will simultaneously need to learn more about the institutional factors (currency invoicing, lags between orders and deliveries, productions lags, etc.) that give rise to these lags so that we can have some solid priors to rely on in the estimation. Econometric advances in recent years can also be fruitfully applied in dealing with the issues of simultaneity and stability that still arise in the area of applied trade. We would certainly recommend that such techniques, discussed at length in Section 3, be utilized in future research on foreign trade relationships. 
Our final priority area for future research is in the area of intercountry differences in price and income elasticities of demand and supply for traded goods. As suggested in Sections 2 and 4, there are many potential explanations for such observed inter-country differences (some relating to the commodity structure of trade, others to shares of imports and exports in domestic consumption and production or in world imports and exports, others to product cycles for new products, etc.), but very little has yet been done on testing these competing explanations. Since differences in elasticities across countries are often as crucial for assessing the trade impacts of income and price changes as the absolute sizes of the elasticities themselves, research on the former topic strikes us as important for understanding these impacts.

Morris Goldstein and Mohsin S. Khan, "Income and Price Effects in Foreign Trade," Reprinted from Ronald W. Jones and Peter Kenen (editors), Handbook of International Economics, Vol 2, pp. 1041-1105, Copyright (1985) with permission from Elsevier.

\section{REFERENCES}

Adams, F.G., et al. (1969), An econometric analysis of international trade (Organization for Economic Cooperation and Development, Paris).

Aghevli, B. and M.S. Khan (1980), "Credit policy and the balance of payments in developing countries", in: W.L. Coats and D.R. Khatkhate, eds., Money and monetary policy in less-developed countries (Pergamon Press, Oxford) $685-711$.

Ahluwalia, I. and E. Hernandez-Cata (1975), "An econometric model of U.S. merchandise imports under fixed and fluctuating exchange rates, 1959-73", IMF Staff Papers, 22:791-824.

Aigner, D.J. and S.M. Goldfeld (1973), "Simulation and aggregation: A reconsideration", Review of Economics and Statistics, 55:114-118.

Aigner, D.J. and S.M. Goldfeld (1974), "Estimation and prediction from aggregate data when aggregates are measured more accurately than their components", Econometrica, 42:113-134.

Alexander, S.S. (1952), "Effects of devaluation on a trade balance", IMF Staff Papers, 2:263-278.

Amano, A. (1974), Export price behavior in selected industrial countries, unpublished (Kobe University, Japan).

Amano, A., A. Muruyama and M. Yoshitomi (1981), A three-country linkage model (Economic Planning Agency, Tokyo). 
Armington, P.S. (1969), "A theory of demand for products distinguished by place of production", IMF Staff Papers, 26:159-178.

Armington, P.S. (1970), "Adjustment of trade balances: Some experiments with a model of trade among many countries", IMF Staff Papers, 27:488-526.

Artus, J.R. (1973), "The short-run effects of domestic demand pressure on export delivery delays for machinery", Journal of International Economics, 3:21-36.

Artus, J.R. (1977), "The behavior of export prices for manufactures", in: P.B. Clark, D.E. Logue and R.J. Sweeney, eds., The effects of exchange rate adjustments (U.S. Treasury, Washington, D.C.), 319-340.

Artus, J.R., (1979), Persistent surpluses and deficits on current account among major industrial countries, unpublished (IMF, Washington, D.C.).

Artus, J.R. and A.K. McGuirk (1981), "A revised version of the multilateral exchange rate model”, IMF Staff Papers, 28:275-309.

Artus, J.R. and R.R. Rhomberg (1973), "A multilateral exchange rate model, IMF Staff Papers", 20:591-611.

Artus, J.R. and S.C. Sosa (1978), "Relative price effects on export performance: The case of nonelectrical machinery", IMF Staff Papers, 25:25-47.

Balassa, B. (1979), "Export composition and export performance in the industrial countries, 1953-71", Review of Economics and Statistics, 61:604-607.

Ball, R.J. and K. Marwah (1962), "The U.S. demand for imports, 1948-1958", Review of Economics and Statistics, 44:395-401.

Ball, R.J., J.R. Eaton and M.D. Steuer (1966), "The relationship between United Kingdom export performance in manufactures and the internal pressure of demand", Economic Journal, 76:501-518.

Ball, R.J., T. Burns and J. Laury (1977), "The role of exchange rate changes in balance of payments adjustment: The United Kingdom case", Economic Journal, 87:1-29.

Barker, T.S. (1970), "Aggregation error and estimates of the U.K. import demand function", in: K. Hilton and D.E. Heathfield, eds., The econometric study of the United Kingdom (London), 115-145.

Barker, T.S. (1976), "Imports", in: T.S. Barker, ed., Economic structure and policy (Chapman and Hall, London), 162-176.

Basevi, G. (1973), "Commodity trade equations in project LINK", in: R. Ball, ed., The international linkage of national economic models (North-Holland, Amsterdam) $227-281$.

Bazdarich, M. (1979), "Has a strong U.S. economy meant a weak dollar"? Federal Reserve Bank of San Francisco Economic Review, Spring:35-46.

Beenstock, M. and P. Minford (1976), A quarterly econometric model of trade and prices 1955-72, in: M. Parkin and G. Zis, eds., Inflation in open economies (Manchester University Press, Manchester).

Bilson, J.F.O. (1979), "The 'vicious circle' hypothesis", IMF Staff Papers, 26:1-37.

Bond, M.E. (1980), "The world trade model: invisibles", IMF Staff Papers, 26:257-333. 
Boylan, T.A., M.P. Cuddy and J. O’Muircheartaigh (1980), “The functional form of the aggregate import demand equation: A comparison of three European economies", Journal of International Economics, 10:561-566.

Box, G.E.P. and D.R. Cox (1964), "An analysis of transformations", Journal of the Royal Statistical Society, 26, Series B: 211-243.

Box, G.E.P. and G.M. Jenkins (1970), Time series analysis: Forecasting and control (Holden-Day, San Francisco).

Branson, W.H. (1968), A Disaggregated model of the U.S. balance of trade, Staff Economic Studies No. 44, Board of Governors of the Federal Reserve System, February.

Branson, W.H. (1972), "The trade effects of the 1971 currency realignments", Brookings Papers on Economic Activity, 15-69.

Branson, W.H. (1980), "Trends in United States international trade and investment since World War II", in: M. Feldstein, ed., The American economy in transition (National Bureau of Economic Research, Chicago), 183-257.

Braun, A. (1976), "Indexation of wages and salaries in developed economies", IMF Staff Papers, 23:226-271.

Brillembourg, A. (1975), "Specification bias in the demand for imports: The case of the Granco-lombian countries”, April, unpublished (IMF, Washington, D.C.).

Brown, R.L., J. Durbin and J.M. Evans (1975), "Techniques for testing the constancy of regression relationships over time", Journal of the Royal Statistical Society, 37, Series B:149-163.

Bruno, M. (1978), "Exchange rates, import costs, and wage-price dynamics", Journal of Political Economy, 86:379-404.

Buckler, M. and C. Almon (1972), Imports and exports in an input-output model, Research Memorandum No. 38, Maryland Inter-Industry Forecasting Project.

Bureau of Labor Statistics (1980), Comparisons of United States, German and Japanese export price indexes (Washington, D.C.).

Burgess, D.F. (1974), "Production theory and the derived demand for imports", Journal of International Economics, 4:103-117.

Cagan, P. (1956), “The monetary dynamics of hyperinflation”, in: M. Friedman, ed., Studies in the quantity theory of money (University of Chicago Press, Chicago), 25-117.

Cheng, H.S. (1959), "Statistical estimates of elasticities and propensities in international trade - a survey of published studies", IMF Staff Papers, 7:107-158.

Chow, G.C. (1960), "Tests of equality between subsets of coefficients in two linear regressions", Econometrica, 28:591-605.

Clark, P.B. (1977), "The effects of recent exchange rate changes on the U.S. trade balance", in: P.B. Clark, D.E. Logue and R.J. Sweeney, eds., The effects of exchange rate adjustments (U.S. Treasury, Washington, D.C.), 201-236.

Clements, K.W. and H. Theil (1978), "A simple method of estimating price elasticities in international trade", Economic Letters, 1:133-137. 
Deardorff, A.V. and R.M. Stem (1977), "International economic interdependence: Evidence from econometric models", unpublished (University of Michigan, Ann Arbor, Mich.).

de Melo, J. and S. Robinson (1981), "Trade policy and resource allocation in the presence of product differentiation", Review of Economics and Statistics, 63: 169-177.

Deppler, M.C. and D.M. Ripley (1978), "The world trade model: Merchandise trade", IMF Staff Papers, 25:147-206.

Dornbusch, R. and S. Fischer (1978), Macroeconomics (McGraw-Hill, New York).

Dornbusch, R. and D.M. Jaffee (1978), "Purchasing power parity and exchange rate problems: Introduction", Journal of International Economics, 8:157-162.

Dornbusch, R. and P. Krugman (1976), "Flexible exchange rates in the short run", Brookings Papers on Economic Activity, 1:143-185.

Dunlevy, J.A. (1979), "Export demand, export supply, and capacity pressure: A simultaneous equations study of American and British export performance", unpublished (Auburn University).

Eckstein, O. and G. Fromm (1968), "The price equation”, American Economic Review, 68:1159-1183.

Edwards, J.B. and G.H. Orcutt (1969), "Should aggregation prior to estimation be the rule?", Review of Economics and Statistics, 51:409-420.

Fair, R.C. (1979), "On modelling the economic linkages among countries", in: R. Dornbusch and J.A. Frenkel, eds., International economic policy - Theory and evidence (The Johns Hopkins University Press, Baltimore), 209-238.

Fair, R.C. and H.H. Kelejian (1974), "Methods of estimation for markets in disequilibrium: A further study", Econometrica, 52:177-190.

Frenkel, J.A. and H.G. Johnson eds. (1976), The monetary approach to the balance of payments (Allen and Unwin, London).

Geraci, V.J. and W. Prewo (1980), "An empirical demand and supply model of multilateral trade", March, unpublished (University of Texas, Texas).

Goldsbrough, D.J. (1981), "International trade of multinational corporations and its responsiveness to changes in aggregate demand and relative prices", IMF Staff Papers, 28:573-599.

Goldstein, M. (1974), "The effect of exchange rate changes on wages and prices in the United Kingdom”, IMF Staff Papers, 21:694-739.

Goldstein, M. (1977), "Downward price inflexibility, ratchet effects and the inflationary impact of import price changes", IMF Staff Papers, 24:569-612.

Goldstein, M. (1980), "Have flexible exchange rates handicapped macroeconomic policy?”, Special Papers in International Economics, No. 14 (Princeton University).

Goldstein, M. and M.S. Khan (1976), "Large versus small price changes and the demand for imports”, IMF Staff Papers, 23:200-225.

Goldstein, M. and M.S. Khan (1978), "The supply and demand for exports: A simultaneous approach", Review of Economics and Statistics, 60:275-286. 
Goldstein, M. and L.H. Officer (1979), "New measures of prices and productivity for tradable and nontradable goods", Review of Income and Wealth, 25:413-427.

Goldstein, M., M.S. Khan and L.H. Officer (1980), "Prices of tradable and nontradable goods in the demand for total imports", Review of Economics and Statistics, 62:190-199.

Granger, C.W.J. (1969), "Investigating causal relations by econometric models and cross-spectral methods", Econometrica, 37:424-438.

Gregory, R. (1971), "United States imports and internal pressure of demand", American Economic Review, 61:28-47.

Grossman, G.M. (1981), "Import competition from developed and developing countries", unpublished (Princeton University, Princeton, N.J.).

Grunfeld, Y. and Z. Griliches (1960), "Is aggregation necessarily bad?", Review of Economics and Statistics, 42:1-13.

Gylfason, T. (1978), "The effect of exchange rate changes on the balance of trade in ten industrial countries", October, unpublished (IMF, Washington D.C.).

Hall, R.E. (1978), "Stochastic implications of the life cycle-permanent income hypothesis: Theory and evidence", Journal of Political Economy, 86:971-988.

Hall, R.E. and R.C. Sutch (1967), "A flexible infinite distributed lag”, paper presented at The Econometric Society Meetings.

Harberger, A.C. (1953), "A structural approach to the problem of import demand", American Economic Review, 43:148-159.

Harberger, A.C. (1957), "Some evidence on the international price mechanism", Journal of Political Economy, 65:506-521.

Hausman, J.A. (1978), “Specification tests in econometrics”, Econometrica, 46:12511272.

Hay, G. (1970), "Production, prices, and inventory theory, American Economic Review”, 60:531-545.

Heien, D.M. (1968), "Structural stability and the estimation of international import price elasticities", Kyklos, 21:695-712.

Hemphill, W.L. (1974), "The effect of foreign exchange receipts on imports of less developed countries", IMF Staff Papers, 21:637-677.

Hickman, B. and L. Lau (1973), "Elasticities of substitution and export demand in a world trade model", European Economic Review, 4:347-380.

Honda, Y. and K. Ohtani, (1980), "The joint specification of functional form and relative price restriction in the aggregate import demand equation", unpublished (Kobe University, Japan).

Hooper, P. (1976), "Forecasting U.S. export and import prices and volumes in a changing world economy”, International Finance Discussion Paper No. 99, Board of Governors of the Federal Reserve System, December.

Hooper, P. (1978), "The stability of income and price elasticities in U.S. trade, 19571977”, International Finance Discussion Paper No. 119, Board of Governors of the Federal Reserve System, June. 
Hooper, P. and S. Kohlhagen (1978), "The effect of exchange rate uncertainty on the prices and volume of international trade", Journal of International Economics, $8: 438-511$.

Hooper, P. and B. Lowry (1979), "The impact of dollar depreciation on the U.S. price level: An analytical survey of empirical estimates", International Finance Discussion Paper No. 128, Board of Governors of the Federal Reserve System.

Houthakker, H.S. and S.P. Magee (1969), "Income and price elasticities in world trade", Review of Economics and Statistics, 51:111-125.

Houthakker, H.S. and L.D. Taylor (1970), Consumer demand in the United States: Analyses and projections (Harvard University Press, Cambridge).

International Bank for Reconstruction and Development (1981), World Development Report 1981 (Washington, D.C.).

Isard, P. (1977a), "The price effects of exchange-rate changes", in: P.B. Clark, D.E. Logue and R.J. Sweeney, eds., The effects of exchange rate adjustments (U.S. Treasury, Washington, D.C.), 369-388.

Isard, P. (1977b), "How far can we push the 'law of one price'?", American Economic Review, 67:942-948.

Johnson, H.G. (1958), International trade and economic growth; Studies in pure theory (Allen and Unwin, London).

Junz, H.B. and R.R. Rhomberg (1965), "Prices and export performance of industrial countries, 1953-63”, IMF Staff Papers, 12:224-269.

Junz, H.B. and R.R. Rhomberg (1973), "Price competitiveness in export trade among industrial countries", American Economic Review, 63:412-418.

Kemp, M.C. (1962a), "Errors of measurement and bias in estimates of import demand parameters", Economic Record, September:369-372.

Kemp, M.C. (1962b), "The demand for Canadian imports: 1926-55” (University of Toronto Press, Toronto).

Kenen, P.B. and C. Pack (1979), "Exchange rates and domestic prices: A survey of the evidence", Research Memorandum, International Finance Section, (Princeton University, Princeton).

Khan, M.S. (1974), "Import and export demand in developing countries, IMF Staff Papers", 21:678-693.

Khan, M.S. (1975), "The structure and behavior of imports of Venezuela", Review of Economic and Statistics, 57:221-224.

Khan, M.S. and K.Z. Ross (1975), "Cyclical and secular income elasticities of the demand for imports", Review of Economics and Statistics, 57:357-361.

Khan, M.S. and K.Z. Ross (1977), "The functional form of the aggregate import equation", Journal of International Economics, 7:149-160.

Kohli, U.R. (1982), "Relative price effects and the demand for imports", Canadian Journal of Economics, May:205-219.

Kmenta, J. (1971), Elements of econometrics (Macmillan, New York).

Kravis, I.B. and R.E. Lipsey (1971), Price competitiveness in world trade (NBER, New York). 
Kravis, I.B. and R.E. Lipsey (1974), "International trade prices and price proxies", in: N. Ruggles, ed., The role of the computer in economic and social research in Latin America (NBER, New York), 253-268.

Kravis, I.B. and R.E. Lipsey (1978), "Price behavior in the light of balance of payments theories", Journal of International Economics, 8:193-246.

Kreinin, M.E. (1961), "Effects of tariff changes on the prices and volume of imports", American Economic Review, 51:297-329.

Kreinin, M.E. (1967), "Price elasticities in international trade", Review of Economics and Statistics, 49:510-516.

Kreinin, M.E. (1977), "The effect of exchange rate changes on the prices and volume of foreign trade", IMF Staff Papers, 24:207-329.

Kreinin, M.E. (1979), International economics (Harcourt Brace Jovanich, New York). Kreinin, M. and L.H. Officer (1978), "The monetary approach to the balance of payments: A survey", Studies in International Finance No. 43 (Princeton University).

Laffer, A.B. (1977), "Exchange rates, the terms of trade, and the trade balance", in: P.B. Clark, D.E. Logue, and R.J. Sweeney, eds., The effects of exchange rate adjustments (U.S. Treasury, Washington, D.C.), 32-44.

Lawrence, R. (1978), "An analysis of the 1977 U.S. trade deficit”, Brookings Papers on Economic Activity, 1:159-190.

Leamer, E.E. (1981), "Is it a demand curve, or is it a supply curve? Partial identification through inequality constraints", Review of Economics and Statistics, 63:319-327.

Leamer, E.E. and R.M. Stem (1970), Quantitative international economics (Allyn and Bacon, Boston).

Lewis, P. (1976), “The weak get weaker with floating rates", New York Times, October 10.

Liu, T.C. (1954), "The elasticity of U.S. import demand: A theoretical and empirical reappraisal”, IMF Staff Papers, 3:416-441.

Lucas, R.E. (1973), "Some international evidence on output-inflation trade-offs", American Economic Review, 63:326-334.

Lucas, R.E. (1976), "Econometric policy evaluation”, in: K. Brunner and A. Meltzer, eds., The Phillips curve and labor market (North-Holland, Amsterdam).

Maddala, G.S. (1977), Econometrics (McGraw-Hill, New York).

Magee, S.P. (1970), "A theoretical and empirical examination of supply and demand relationships in U.S. international trade", unpublished, (Council of Economic Advisers, Washington, D.C.).

Magee, S.P. (1972), "Tariffs and U.S. trade", unpublished (Council of Economic Advisers, Washington, D.C.).

Magee, S.P. (1973), "Currency contracts, pass-through, and devaluation", Brookings Papers on Economic Activity, 1:303-323.

Magee, S.P. (1975), "Prices, income and foreign trade: A survey of recent economic studies", in: P.B. Kenen, ed., International trade and finance: Frontiers for research (Cambridge University Press, Cambridge). 
Magee, S.P. and R. Rao (1980), "Vehicle and nonvehicle currencies in international trade", American Economic Review, 70:368-373.

McCloskey, D.N. and J.R. Zecher (1976), "How the gold standard worked, 19801913", in: J.A. Frenkel and H.G. Johnson, eds., The monetary approach to the balance of payments (Allen and Unwin, London), 357-385.

McKinnon, R. (1978), "Exchange rate instability, trade imbalances, and monetary policies in Japan and the United States", unpublished (Stanford University, Stanford, CA.).

Miles, M.A. (1979), "The effects of devaluation on the trade balance and the balance of payments: Some new results", Journal of Political Economy 87:600-620.

Minford, P. (1978), Substitution effects, speculation and exchange rate stability (North-Holland, Amsterdam).

Mintz, I. (1967), Cyclical fluctuations in the exports of the United States since 1879, Studies in Business Cycles No. 15 (NBER, New York).

Morgan, D.I. and W.J. Corlett (1951), "The influence of price in international trade: A study in method", Journal of the Royal Statistical Society 114, Series A:307-358.

Murray, T. and P. Ginman, (1976), "An empirical examination of the traditional aggregate import demand model", Review of Economics and Statistics, 58:75-80.

Mutti, J.H. (1977), "The specification of demand equations for imports and domestic substitutes", Southern Economic Journal, 44:68-73.

Okun, A. (1975), "Inflation: Its mechanics and welfare costs", Brookings Papers on Economic Activity, 2:351-501.

Orcutt, G. (1950), "Measurement of price elasticities in international trade", Review of Economics and Statistics, 32:117-132.

Prais, S.J. (1962), "Econometric research in international trade: A review", Kyklos, 15:560-577.

Ramsey, J.B. (1969), "Tests for specification errors in classical least-squares regression analysis", Journal of the Royal Statistical Society, 31, Series B:350-371.

Rhomberg, R.R. (1973), "Towards a general trade model”, in: R.J. Ball, ed., The international linkage of national economic models (North-Holland, Amsterdam), 9-20.

Rhomberg, R.R. and L. Boissonneault (1965), “The foreign sector”, in: The Brookings quarterly econometric model of the United States, (Rand McNally, Chicago), $375-406$.

Richardson, J.D. 1973, "Beyond (but back to?) the elasticity of substitution in international trade", European Economic Review, 4:381-392.

Robinson, P., T. Webb and M. Townsend (1979), "The influence of exchange rate changes on prices: A study of 18 industrial countries", Economica, 46:27-50.

Sachs, J. (1980), "Wage indexation, flexible exchange rates, and macroeconomic policy”, Quarterly Journal of Economics, 94:731-748.

Sachs, J. (1981), "The current account and macroeconomic adjustment in the 1970s", Brookings Papers on Economic Activity, 1:201-268. 
Salant, W. (1977), "International transmission of inflation", in: L. Krause and W. Salant, eds., Worldwide inflation (Brookings Institution, Washington), $167-226$.

Samuelson, L. (1973), "A new model of world trade", OECD Occasional Studies (Organization for Economic Cooperation and Development, Paris).

Sargent, T.J. (1976), "The observational equivalence of natural and unnatural rate theories of macroeconomics", Journal of Political Economy, 84:631-640.

Santomero, A. and J. Seater (1978), "The inflation-unemployment trade-off: A critique of the literature", Journal of Economic Literature, 16:499-544.

Sims, C. (1971), "Discrete approximations to continuous time distributed lags in econometrics", Econometrica, 39:545-564.

Sims, C. (1972), "Money, income, and causality", American Economic Review, 62:540-552.

Spitaeller, E. (1978), "A model of inflation and its performance in the seven main industrial countries, 1958-76", IMF Staff papers, 25:254-277.

Spitaeller, E. (1980), "Short-run effects of exchange rate changes on terms of trade and trade balance", IMF Staff Papers, 27:320-348.

Stern, R.M., J. Francis and B. Schumacher (1976), Price elasticities in international trade - An annotated bibliography (Macmillan, London).

Stern, R.M., C.F. Baum and M.N. Greene (1979), "Evidence on structural change in the demand for aggregate U.S. imports and exports", Journal of Political Economy, 87:179-192.

Stone, Joe A. (1979), "Price elasticities of demand for imports and exports: Industry estimates for the U.S., the E.E.C. and Japan", Review of Economics and Statistics, 61:117-123.

Taplin, G.B. (1973), “A model of world trade”, in: R.J. Ball, ed., The international linkage of national economic models (North-Holland, Amsterdam), 177-223.

Theil, H. (1954), Linear aggregation of economic relations (North-Holland, Amsterdam).

Theil, H. and K.W. Clements (1978), "A Differential Approach to U.S. Import Demand", Economics Letters, 1:249-254.

Truman, E. (1978), "Balance-of-payments adjustment from a U.S. perspective: The lessons of the 1970's", unpublished (Board of Governors of the Federal Reserve System, Washington, D.C.).

Vernon, R. (1966), "International Investment and International Trade in the Product Cycle", Quarterly Journal of Economics, 80:191-207.

Wallich, H. (1978), "Reflections on the U.S. balance of payments", Challenge March/April, 34-40.

Weisskoff, R. (1979), "Trade, protection and import elasticities for Brazil”, Review of Economics and Statistics, 51:58-66. 
Wilson, J.F. and W. Takacs (1979), "Differential responses to price and exchange rate influences in the foreign trade of selected industrial countries", Review of Economics and Statistics, 51:267-279.

Winters, L.A. (1976), "Exports", in: T.S. Barker, ed., Economic structure and policy (Chapman and Hall, London), 131-161.

Wymer, C.E. (1972), "Econometric estimation of stochastic differential equation systems", Econometrica, 40:565-577. 